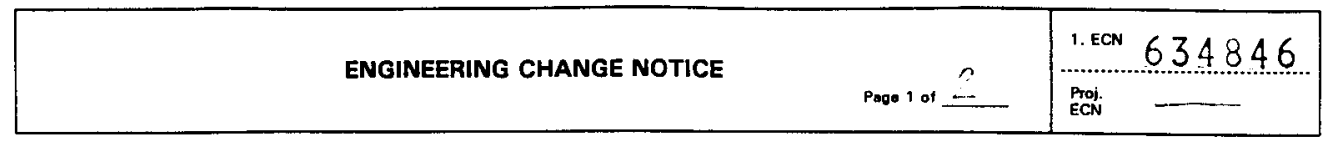

\begin{tabular}{|c|c|c|c|c|c|}
\hline \multirow{3}{*}{$\begin{array}{l}\text { 2. ECN Category } \\
\text { (mark one) } \\
\\
\text { Supplemental } \\
\text { Direct Revision } \\
\text { Change ECN } \\
\text { Temporary } \\
\text { Standby } \\
\text { Supersedure } \\
\text { Cancel/Void }\end{array}$} & \multicolumn{2}{|c|}{$\begin{array}{l}\text { 3. Originator's Name, Organization, MSIN, } \\
\text { and Telephone No. } \\
\text { K. Wa Tterskirchen/FDNW-T/SW } \\
\text { Projects/G3-17 }\end{array}$} & \multicolumn{2}{|c|}{$\begin{array}{l}\text { 4. USQ Required? } \\
{[] \text { Yes }[X] \text { No }}\end{array}$} & $\begin{array}{l}\text { 5. Date } \\
3 / 26 / 97\end{array}$ \\
\hline & \multicolumn{2}{|c|}{$\begin{array}{l}\text { 6. Project ritle/No./Work Order No. } \\
\text { WESF/Hot Cells Waste } \\
\text { Minimization Criteria/E57618 }\end{array}$} & \multicolumn{2}{|c|}{$\begin{array}{l}\text { 7. Bldg./Sys./Fac. No. } \\
\text { WESF }\end{array}$} & $\begin{array}{l}\text { 8. Approval Designator } \\
\qquad N / A\end{array}$ \\
\hline & \multicolumn{2}{|c|}{$\begin{array}{l}\text { 9. Document Numbers Changed by this ECN } \\
\text { (includes sheet no. and rev.) } \\
\text { HNF -SD-E57618-ER-001 }\end{array}$} & \multicolumn{2}{|c|}{$\begin{array}{l}\text { 10. Related ECN No(s). } \\
\text { N/A }\end{array}$} & $\begin{array}{l}\text { 11. Related PO No. } \\
\qquad N / A\end{array}$ \\
\hline \multirow{2}{*}{$\begin{array}{l}\text { 12a. Modification Work } \\
{[] \text { Yes (fill out Blk. }} \\
12 b \text { ) } \\
{[x] \text { No (NA Blks. 12b, }} \\
12 c, 12 d \text { ) }\end{array}$} & \multirow[t]{2}{*}{$\begin{array}{l}\text { 12b. Work Package } \\
\text { No. } \\
\text { N/A }\end{array}$} & \multicolumn{2}{|c|}{$\begin{array}{l}\text { 12c. Modification Work Complete } \\
\text { N/A }\end{array}$} & \multicolumn{2}{|c|}{$\begin{array}{l}\text { 12d. Restored to Original Condi- } \\
\text { tion (Temp. or Standby ECN only) } \\
N / A\end{array}$} \\
\hline & & \multicolumn{2}{|c|}{$\begin{array}{c}\text { Design Authority/Cog. Engineer } \\
\text { Signature \& Date } \\
\end{array}$} & \multicolumn{2}{|c|}{$\begin{array}{l}\text { Design Authority/Cog. Engineer } \\
\text { Signature \& Date }\end{array}$} \\
\hline \multicolumn{2}{|c|}{$\begin{array}{l}\text { 13a. Description of change } \\
\text { Total revision of the document. }\end{array}$} & 13b. Design Basel ine & ocument? & Yes & No \\
\hline
\end{tabular}

14a. Justification (mark one)

Criteria Change $[X]$ Design Improvement [] Environmental

As-Found [] Facilitate Const [] Const. Error/Omission [] Design Error/Omission []

14b. Justification Details

Criteria changes

15. Distribution (include name, MSIN, and no. of copies)

See Distribution List, per

* Doc Transmital - FDNVr-EB:18.0ri 


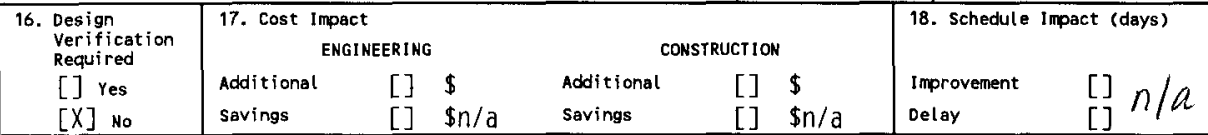

19. Change Impact Review: Indicate the related documents (other than the engineering documents identified on side 1) that will be affected by the change described in Block 13. Enter the affected document number in Block 20.

$\begin{array}{ll}\text { SDD/DD } & {[]} \\ \text { Functional Design Criteria } & {[]} \\ \text { Operating Specification } & {[]} \\ \text { Criticality Speoification } & {[]} \\ \text { Conceptual Design Report } & {[]} \\ \text { Equipment Spec. } & {[]} \\ \text { Const. Spec. } & {[]} \\ \text { Procurement Spec. } & {[]} \\ \text { Vendor Information } & {[]} \\ \text { OM Manual } & {[]} \\ \text { FSAR/SAR } & {[]} \\ \text { Safety Equipment List } & {[]} \\ \text { Radiation Work Permit } & {[]} \\ \text { Environmental Impact Statement } & {[]} \\ \text { Environmental Report } & {[]} \\ \text { Environmental Permit } & {[]}\end{array}$

[] Soismic/Stress Analysis

[] Stross/Design Roport

[] Interface Control Drawing

[] Calibration Procedure

[] Installation Proceduro

[] Maintenance Procedure

[] Engineering Procedure

[]

Tank Calibration Manuat

[] Operating Instruction

[]

Hoalth Physics Procedure

[]

[]

[]

[] Operating Procedure

[] Operational Safety Requirement

[] IEFD Drawing

[] Cell Arrangement Drawing

[] Essontial Material Specification

[]

[]

[]

[]

[]

[]

Spares Multiple Unit Listing

Fac. Proc. Samp. Schedule

[]

[]

[]

Test Procedures/Specification

Component Indox

Inspection Plan

[]

ASME Coded Item

Human Factor Consideration

Computer Software

Electric Circuit Schedule

ICRS Procedure

Process Control Manual/Plan

Process Flow Chart

20. Other Affected Documents: (NOTE; Documents listed below will not be revised by this ECN.) Signatures below indicate that the signing organization has been notified of other affected documents listed below.

Document Number/Revision

Document Number/Revision

Document Number Revision

$\mathrm{n} / \mathrm{a}$

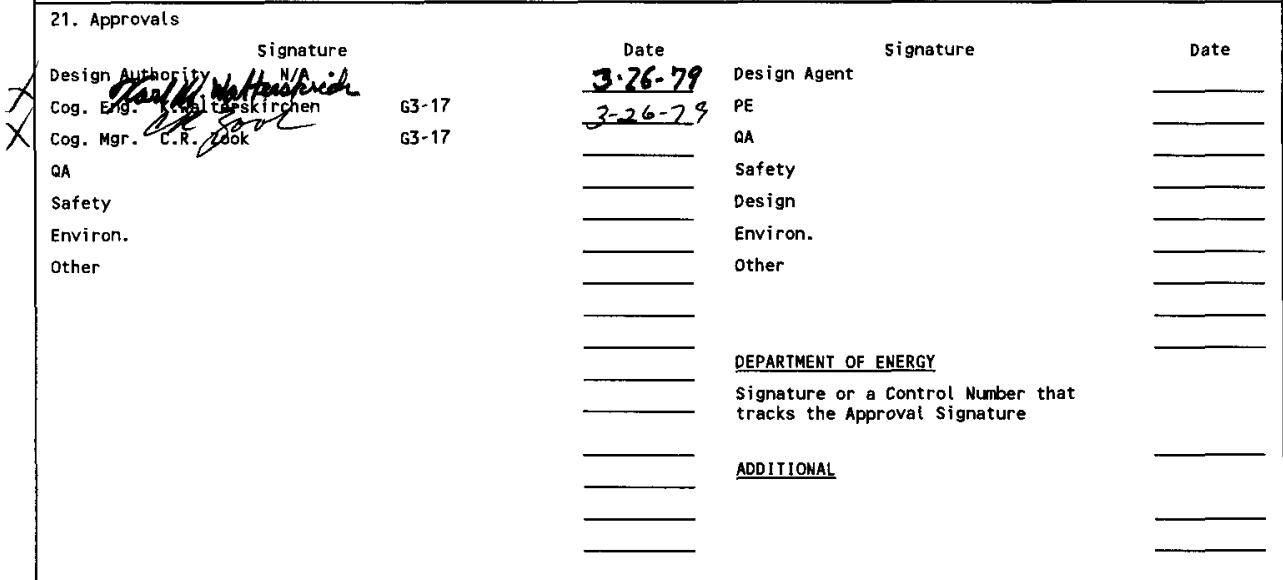


RECORD OF REVISION

(2) Title

WESF Hot Cells Waste Minimization Criteria Part 1 of 2: Window Seals Evaluation

CHANGE CONTROL RECORD

\begin{tabular}{|c|c|c|c|}
\hline \multirow{2}{*}{ (3) Revision } & \multirow{2}{*}{ (4) Description of Change - Replace, Add, and Delete Pages } & \multicolumn{2}{|c|}{ Authorized for Release } \\
\hline & & (5) Cog. Engr. & (6) Cog. Mgr. Date \\
\hline 0 & (7) Initial Release EDT-618912 & $\begin{array}{l}\text { K. Walter- } \\
\text { skirchen }\end{array}$ & C.R. Zook \\
\hline $1 \mathrm{RS}$ & ECN-634846 Direct Revision of document & $\begin{array}{l}\text { K. Walter } \\
\text { skirchens, }\end{array}$ & $\begin{array}{l}\text { C.R. Zook } 3 / 26 / 97 \\
\text { LeT }\end{array}$ \\
\hline & & & \\
\hline & & & \\
\hline & & & \\
\hline & & & \\
\hline & & & \\
\hline & & & \\
\hline & & & \\
\hline & & & \\
\hline & & & \\
\hline & & & \\
\hline & & & \\
\hline & & & \\
\hline & & & \\
\hline & & & \\
\hline & & & \\
\hline & & & \\
\hline & & & \\
\hline & & & \\
\hline & & & \\
\hline & & & \\
\hline & & & \\
\hline & & & \\
\hline & & & \\
\hline & & & \\
\hline & & & \\
\hline & & & \\
\hline & & & \\
\hline & & & \\
\hline & & & \\
\hline
\end{tabular}




\section{WESF Hot Cells Waste Minimization Criteria Hot Cells Window Seals Evaluation}

K. M. Walterskirchen

Fluor Daniel Northwest, Richland, WA 99352

U.S. Department of Energy Contract DE-AC06-87ft-10930

96RL $13200 \mathrm{gm} 3 / 26 / 97$

EDT/ECN: 634846

Org Code: O4E00/454

B\&R Code: EW7050000
UC: 721

Charge Code: E57618

Total Pages: $46-50 \mathrm{gm} \mathrm{3/26/97}$

Key Words: WESF, Hot Cells, Window Seals, Waste Minimization

Abstract: WESF will decouple from B Plant in the near future. WESF is attempting to minimize the contaminated solid waste in their hot cells and utilize B Plant to receive the waste before decoupling. WESF wishes to determine the minimum amount of contaminated waste that must be removed in order to allow minimum maintenance of the hot cells when they are placed in "laid-up" configuration. The remaining waste should not cause unacceptable window seal deterioration for the remaining life of the hot cells. This report investigates and analyzes the seal conditions and hot cell history and concludes that WESF should remove existing point sources, replace cerium window seals in F-Cell and refurbish all leaded windows (except for A-Cell). Work should be accomplished as soon as possible and at least within the next three years.

TRADEMARK DISCLAIMER. Reference herein to any specific commercial product, process, or service by trade name, trademark, manufacturer, or otherwise, does not necessarily constitute or imply its endorsement, recommendation, or favoring by the United States Government or any agency thereof or its contractors or subcontractors.

Printed in the United States of America. To obtain copies of this document, contact: WHC/BCS Document Control Services, P.O. Box 1970, Mailstop H6-08, Richland WA 99352, Phone (509) 3722420; Fax (509) 376-4989.
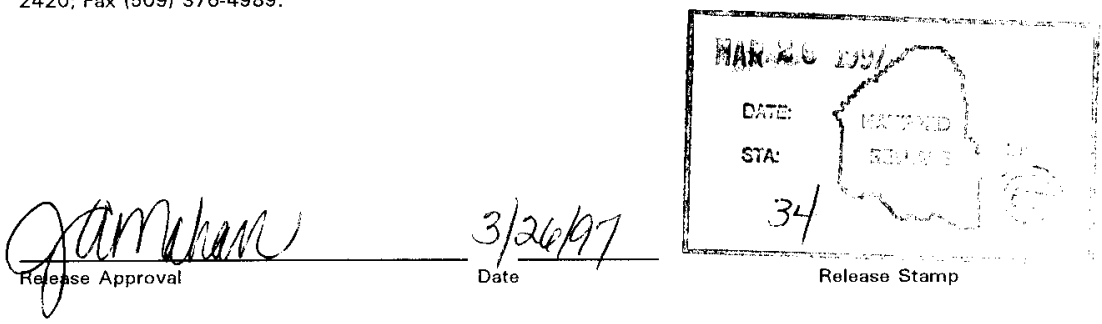

\section{Approved for Public Release}




\section{ENGINEERING REPORT}

\section{WESF HOT CELLS \\ WASTE MINIMIZATION CRITERIA \\ Hot Cells Window Seals Evaluation}

Work Order E57618

Prepared by

Fluor Daniel Northwest

Richland, Washington

for

B\&W Hanford Company

Richland, Washington

Fluor Daniel Northwest

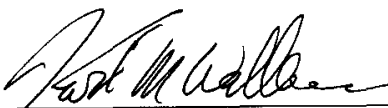

K. M. Walterskirchen, Lead Engineer

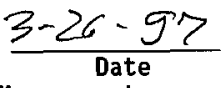

Mechanical Engineering, Facilities Stabilization/Utilities Management

C. R. Zook, Mechanical Engineering Lead

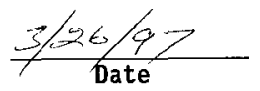
Mechanical Engineering, Facilities Stabilization/Utilities Management

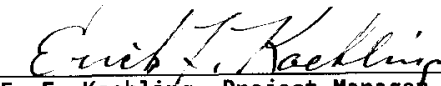

E. F. Koehling, Project Manager

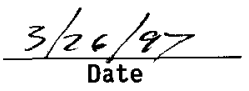

WESF Decoupl ing Prject, WESF Capsule Management Team 
Engineering Report

WESF HOT CELLS

WASTE MINIMIZATION CRITERIA

Hot Cells Window Seals Evaluation

WORK ORDER E57618

Prepared for the U.S. Department of Energy

Assistant Secretary of Environmental Management

Project Hanford Management Contractor for the

U.S. Department of Energy under Contract DE-AC06.96RL13200

Approved for public release; distribution is unlimited 


\section{TABLE OF CONTENTS}

Paqe

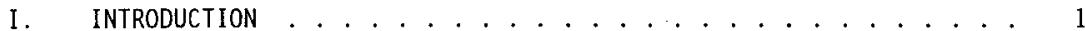

II. SCOPE .......................... 2

III. SUMMARY . . . . . . . . . . . . . . . . . . . . . . 3

IV. DATA COLLECTION . . . . . . . . . . . . . . . . . . . . 5

V. HOT CELLS CONFIGURATION ..................... 5

VI. HOT CELLS HISTORY . . . . . . . . . . . . . . . . . . . . . . . . 6

VII. ANALYSIS . . . . . . . . . . . . . . . . . . 7

VIII. RESULTS AND CONCLUSIONS . . . . . . . . . . . . . . . . . . . . . . 8

IX. RECOMMENDATIONS ....................... . . . 10

X. REFERENCES ........................... 11

A. DOCUMENTS . . . . . . . . . . . . . . . . . . . . . . . 11

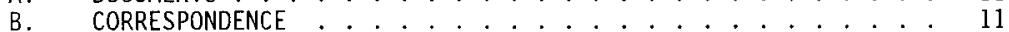

\section{APPENDICES}

Appendix A: Drawings

Appendix B: Radiation Calculation and Figures

Appendix C: Data Collection Logs

Appendix D: Hot Cells History

Appendix E: Seal Material Specifications 


\section{ENGINEERING REPORT}

\section{WESF HOT CELLS \\ WASTE MINIMIZATION CRITERIA}

Hot Cells Window Seals Evaluation

Work Order E57618

\section{INTRODUCTION}

The B Plant/Waste Encapsulation and Storage Facility (WESF) has a mission to decouple the WESF operations from B Plant to will allow WESF to operate independently from B Plant and to allow the deactivation and decommissioning of B Plant. The waste minimization effort, as part of the decoupling, will remove contaminated waste from the WESF hot cells sufficient to allow certain cells to be converted into a "laid-up" configuration. The laid-up configuration includes the following:

- Hot cells "cleaned and decontaminated"

- Hot cells isolated from potential liquid sources

- Manipulators removed and ports plugged

- Hot cell maintenance minimized

- Hot cells capable of being restored for future use

The problem facing WESF is to determine the least amount of radioactive waste removal and decontamination that can be done for the least cost to convert the selected cells into a laid-up configuration. Establishing the amount of radioactive waste removal, the scope of window refurbishment required to maintain useful cells and when waste removal and refurbishment should occur (urgency) relates to its cost effectiveness.

To facilitate this effort. Fluor Daniel Northwest (FDNW) was requested to investigate the condition of the hot cells and to provide a document that identifies the following: cleanout/decontamination criteria in A-, B-, C-, D-, E-, F-, and $\mathrm{G}-\mathrm{Cellis}$; ventilation requirements and maximum surface level contamination levels; and instrumentation which can be deactivated or removed. The document also evaluates the integrity of the existing seal material and provides an estimate of 
the remaining life of the seals. A separate report will evaluate the instrumentation and ventilation requirements.

\section{SCOPE}

The scope of work for this report is defined in two Letters of Instructions (LOI) received from $B \& W$ Hanford Company (BWHC) (References $B 1$ and $B 2$ ). BWHC requested FDNW to provide engineering services to support $B$ Plant/WESF decoupling and WESF waste minimization activities. This specific task identifies the requirements and criteria to be used in substantiating project positions regarding hot cell cleanup in WESF.

Specific tasks defined in the LOls include the following:

1. Identify the cleanout/decontamination criteria for the WESF hot cells A- through G-Cell to allow the following:

a. Hot cell windows maintained in a safe, low maintenance. configuration.

b. Manipulators removed from A-through E-Cells.

c. Deliverable: Provide documentation specifying requirements to accomplish the above activities.

2. Identify ventilation requirements to place the WESF hot cells in a laid-up configuration, including the following:

a. Dose and surface contamination levels allowable to preclude shield window seal failure.

b. Ventilation flow and differential pressure requirements to preclude contamination mitigation to F-Cell and G-Cell, Operation Gallery, Service Gallery, A-Cell Airlock and Canyon area.

c. Maximum surface contamination levels allowable to facilitate reduction of ventilation requirements.

d. Deliverable: Provide documentation specifying requirements to accomplish the above activities. 
3. Based on the results from 1 and 2, identify WESF instrumentation which will no longer be required and could be deactivated/ removed, considering the following:

a. Continued support of the known WESF mission.

b. Capability to restore existing ventilation system functions, if required.

c. Deliverable: Provide potential list of instruments no longer required, providing justification for removal, and develop plan for logical/sequential removal of listed equipment.

FDNW has divided the tasks into separate engineering reports (deliverables). This report addresses task item 1 including the life of the hot cell window seals, allowable radiation levels and the recommended actions for hot cell contamination cleanup. The second report will address task items 2 and 3 , including the instrumentation and ventilation requirements.

\section{SUMMARY}

FDNW performed the research and analysis to evaluate the life expectancy of the existing hot cell window seals. The summary, results, conclusions, and recommendations are as follows:

- The radiation sources in the hot cells affecting window seals were determined to be the following:

Surface Contamination Sources:

A-Cell Dose rate @ windows $\quad=100 \mathrm{R} / \mathrm{hr}$

B- through F-Cell Dose rate @ windows = $3,500 \mathrm{R} / \mathrm{hr}$

The surface contamination radiation level dose rates are average estimated values based on a 1992 survey of one of the cells.

Point Sources:

F-Cell

Three cesium capsules in storage

G-Cell

775 cesium capsules and 4 strontium capsules received, unpacked and inspected for pool storage 
- The window seals in a typical cell window assembly include the gaskets (seals) in the protective cerium coverglass (cerium window) located in the cell and the gaskets (seals) in the primary lead glass viewing window (leaded window). From information obtained from WESF personnel and vendors who have supplied seal material to WESF, it is reasonably certain that the existing cerium window seal material is Adiprene L-83 (Uniroyal), $1 \times 10^{9} \mathrm{R}$, and that the existing leaded window seal material is Koroseal 116 ,

$1 \times 10^{8} \mathrm{R}$. The oil in the leaded windows is assumed to have a radiation limit of $1 \times 10^{8}$, which is typical for mineral oil.

- There are many variables which could affect the life of the hot cell window seals: radiation, material properties, installation, tempering, oil deterioration, etc. The calculations in the analysis of this report concern the effects of radiation alone. The calculation results should be used primarily as an indicator of impending seal failure from excessive radiation exposure and not as a prediction of seal life as a basis for long term planning. FDNW calculates the expiration dates for the seal materials for radiation alone as follows:

$\begin{array}{lll} & \text { Leaded Window Seals } & \text { Cerium Window Seals } \\ & \text { Good through } & \text { Good through } \\ \text { A-Cell: } & 2015+ & 2015+ \\ \text { B-Cell: } & 1987 \text { expired } & 2015+ \\ \text { C-Cell: } & 1987 \text { expired, leaking } & 2015+ \\ \text { D-Cell: } & 1987 \text { expired } & 2015+ \\ \text { E-Cell: } & 1987 \text { expired } & 2015+ \\ \text { F-Cell: } & 1992 \text { expired, excessive dosage } & 1994 \text { expired } \\ \text { G-Cell: } & 1993 \text { expired, excessive dosage } & 2015+\end{array}$

There is currently substantial overexposure of both window seals in F-Cell and G-Cell due to point source radiation exposure and substantial overexposure of all of the leaded window seals. In addition, the C-Cell window is leaking oil into the cell, presumably the result of a failed leaded window seal. The leaded window seals (Koroseal 116) exposed and observable from the operator's gallery are brittle and ineffective as a proper seal. FDNW concludes that all of the seals are suspect and could fail at any time.

To allow WESF to place A-through G-Cell in a laid-up configuration (or fully operational in the case of G-Cell) FDNW recommends WESF (1) remove or protect the capsules in F-Cell, (2) replace the cerium window seals in F-Cell and G-Cell, (3) refurbish the $\mathrm{C}$-Cell leaded window, (4) refurbish the $\mathrm{F}$-Cell leaded window, (5) refurbish both $\mathrm{G}-\mathrm{C}$ ell leaded windows and (6) refurbish the remaining leaded 
windows, with priorities in that order. All of the work should be completed as soon as possible but at least within the next two to three years.

\section{DATA COLLECTION}

Through meetings and correspondence with WESF personnel and others previously associated with the hot cell operations, information was obtained regarding the window materials, previous window replacement and refurbishment, and the general history of the hot cells operation. Seal and window manufacturers including Hot Cell Services, Viox, Penberthy, B.F. Goodrich, and Uniroyal were also contacted as sources for performance specifications on new and existing seal material. The data collection efforts, including the information received from personnel contacted, meetings, and correspondence, are provided in more detail in Appendix C, Data Collection Logs.

The seal material specifications and data provided by Hot Cell Services Corporation is the primary source of seal criteria for the analysis, and are included in Appendix E.

\section{HOT CELLS CONFIGURATION}

The physical layout of the WESF hot cells, including cell cross sections and typical window details are shown in Appendix A, Drawings. Drawing D1 is a floor plan of the cells which shows the relationship of the cells to each other and adjacent areas and shows the location of the known high radiation sources. A section through F-Cell, Drawing D2, shows the location of the cesium capsules with respect to the window. Drawing D3 is typical section of the other cells. It shows the oil leakage from C-Cell window and it shows the approximate location of the contamination migration through the damaged floors in D-Cell and F-Cell.

Drawing D4 is a cross section of a typical cell window showing the components of the window and the window framework. The cerium window assembly, which is installed on the inside face of the hot cell window, protects the leaded glass window and provides an air-tight primary barrier to allow the primary leaded glass window to be removed into the operation gallery for maintenance without contaminating the area. The seal materials being evaluated are located at two locations in the cerium window assembly and four locations in the leaded glass window assembly. The seals (Koroseal 116) in the leaded glass window assembly

- are installed within the two face plates which house the leaded glass and oil. The 
cerium window seals (Adiprene L-83) function as an air tight seal between the glass, the assembly frame, and the wall. This allows the hot cell to be maintained at a negative pressure from the operating gallery. The leaded window seals are strictly oil seals. Lead wool or similar material is used to pack around the leaded window assembly after it is inserted into the wall cavity.

A failed cerium window seal, even a negative pressure maintained in the cell, will allow contamination to migrate into the small air space between the two window assemblies and possibly into the wall cavity and operating gallery. Window maintenance becomes very difficult and hazardous if contamination occurs.

Oil is used to fill the voids between the multiple lead glass plates in the leaded window assembly. The plates require a certain spacing to prevent Newton's rings from appearing. The oil is a natural filler because it matches the refraction characteristics of the lead glass plates. The failure of a leaded glass window seal will result in oil leakage. Depending on where the leak is, the oil could spill either into the hot cell and create additional contaminated waste, which is difficult to remove, or into the operating gallery, or both.

\section{HOT CELLS HISTORY}

The WESF was constructed in 1973. Waste processing in the hot cells began in 1974. The production of the cesium and strontium capsules lasted from 1974 to 1985. The activities that occurred in each cell and the history of the waste process and encapsulation during this period is provided in Appendix D, Hot Cells History.

This report is primarily concerned with the later period after 1984 when the windows were refurbished and the current seals installed. This report considers 1985 the first year of operation after window refurbishment. Of particular concern is the storage of the three cesium capsules in F-Cell, one stored in 1991, one in 1993, and one in 1995. From these capsules, F-Cell window has received substantially more radiation exposure than any other cell windows. G-Cell window, which experienced the return of the capsules during the years from 1988 to 1995 , should also show a fair amount of accumulated radiation exposure. There were a few hours of exposure from each capsule being unpacked and examined prior to storage in the pool. The other cell windows only experienced exposure from contaminated wastes being left in the cells or surface contamination remaining on walls, floors, etc., which is a much lower radiation level than the capsules. However, this type of radiation source can not be defined as well as an easily

- definable source like the cesium capsules (considered a point source for the purpose 
of this report). Without a radiological survey of the cells, these windows must be analyzed based on an estimated background dose rate.

\section{ANALYSIS}

The objective for performing the calculations for this report is to determine expected dose rates from cesium and strontium capsules and, using this data, evaluate the severity of the damage to the hot cells window seal material. The results should be values of dose rates experienced by the seals and in life expectancy of the material in years. The analysis shows the radiation resistance values for both the $1 \times 10^{9} \mathrm{R}$ and $1 \times 10^{8} \mathrm{R}$ rated materials used in the cerium windows and the leaded windows respectively.

The analysis and calculations are included as Appendix B, Radiation Calculations, and Figures F1, F2, F3, F4, and F5.

Calculations comparing the original theoretical activity values of a cesium capsule and a strontium capsule show that the dose rate from a cesium capsule is much higher than that of a strontium capsule. Therefore, the radiation damage to seal material from cesium capsule is more severe than that from a strontium capsule.

A-Cell windows, including the smaller hood window, received very little radiation based on the constant $100 \mathrm{R} / \mathrm{hr}$ value assumed. FDNW concluded that the A-Cell seals received negligible radiation damage and will not be a factor in considering the cell for laid-up status. This does not preclude seal failure for other reasons which are addressed in Appendix B.

B-, C-, D-, and E-Cells have an assumed constant dose rate of $3500 \mathrm{R} / \mathrm{hr}$ ton average) based on design criteria from WESF (Appendix B, pg B2). Assuming that radiation is the only detrimental element affecting the seals, the possible service life of the cerium window seal material in these cells is 32.62 years (pg B5) or until the year 2017. However, the leaded window seals have a service life of only 3.26 years and have been overexposed since 1987 (pg B5).

The seal material use in the hot cell cerium windows is Adiprene L-83 (Uniroyal) having maximum allowable radiation dosage limit of $1 \times 10^{9} \mathrm{R}$ (Appendix $E$, pg E6). This is supported in report SD-WM-ER-013, "WESF E-Cell Cerium Coverglass Changeout," (Ref 3 ).

A material specification sheet for cast sheet, polyurethane, and polyether was received from WESF during the information gathering efforts (Appendix $E$, pg E10). 
It stated that, "The gasket material shall be a one piece sheet of cast polyurethane, with a nuclear radiation tolerance of $1 \times 10^{8} \mathrm{R}$ total dose and a Shore $A$ hardness of 82." It is assumed that the leaded window seal material was procured under this specification and that the material was Koroseal 116. This is supported by correspondence from Hot Cells Services Corporation (Appendix E, pg E2) who refurbished most of the leaded windows in 1985. Figures F4 and F5 (Appendix B) shows the service life of both materials, one with $1 \times 10^{9} \mathrm{R}$ and one with $1 \times 10^{8}$ $R$ and indicate the much greater protection from radiation provided by Adiprene L-83.

In F-Cell, there are three cesium capsules which were returned with possible damage and could not be stored in the pool. The cumulative dosage during the analysis period from January 1991, when the first capsule was stored, to January 1 1 1997, the current date for the purpose of this report, is calculated to be $1.34 \mathrm{E}+09 \mathrm{R}(\mathrm{pg} \mathrm{B} 6)$.

Figure F5 (pg B11) is a plot of Cumulative Dose versus Years for F-Cell seals. It shows that the last two capsules, which were placed $2 \mathrm{ft}-6 \mathrm{in}$. (estimated) from the window, are the major dose contributors. However, the cumulative dosage received from the three capsules by all the seals in F-Cell during the analysis period is substantially higher than the limits of both seal materials. In particular the leaded window seals which are Koroseal 116 have been severely overexposed to radiation and probably retain very little of the materials original properties which allow it to function as a seal. As of the preparation of this report the three capsules remain in storage in F-Cell and continue to cause deterioration of the seals. It is probable that more window seals will fail in the near future and any window can fail at any time. Some of the overexposed cerium window seals may have already failed and may not be capable of functioning properly as an air seal should the leaded windows be removed.

G-Cell was used to process returned commercial capsules which were unpacked, inspected, and stored in the pool. Records show that a total of 775 cesium capsules and four strontium capsules were returned through G-Cell between 1991 and 1996 . The total dosage received by the seal material is calculated to be $1.33 \times 10^{8} \mathrm{R}$, which is considerably less than $1 \times 10^{9} \mathrm{R}$ but slightly greater than $1 \times 10^{8} \mathrm{R}$. The cumulative dosage versus time for $\mathrm{G}$-Cell seals is also plotted in Figure $F 4$ (pg B10). The cerium window seal material of G-Cell may still have good resistance to radiation but the leaded window seals are theoretically overexposed since 1993.

\section{RESULTS AND CONCLUSIONS}


The analyses performed for the evaluation of window seal life expectancy have provided values which are theoretical and related totally to deterioration from radiation. Many other uncertainties remain which make any seal life predictions suspect. The failure of $\mathrm{C}$-Cell window is assumed to be the result of excessive radiation damage to the leaded window seals (Koroseal 116). However, the failure could be the result of seal material flaws (bubbles in the gasket material matrix), the installation of material that had exceeded its shelf life or experienced improper storage conditions (humidity, temperature), or improper installation of the window or seals.

Vendor's specification for the maximum allowable dose accumulation limit usually is based on statistical analyses of laboratory data obtained from accelerated dose exposure experiments with high levels of exposure. Field data from actual in-use applications is very limited. The use of these materials in radioactive environments extremely limits both in-field and laboratory observations and adds to the uncertainty of the limits established by the vendor.

Questionable radiation resistance values, plus the uncertainties described above, make it impossible to evaluate any meaningful seal life expectancy purely from an analytical basis. From a practical basis, with the knowledge of the seal material and the amount and length of time radioactive material was stored in the cells, window failure could occur at any time in any window and will occur in the near future. With these uncertainties in mind, FDNW provides the following results and conclusions:

1. Calculations show that window seal damage from cesium is 30 times more severe than strontium. The effects of damage from each are tabulated in Figure F1 and are shown graphically in Figures F2 and F3, Appendix B.

2. Radiation accumulation by the A-Cell window seals at a constant dose rate of $100 \mathrm{R} / \mathrm{hr}$ is considered negligible and inconsequential for cell lay up considerations.

3. Radiation accumulation by B-, C-, D-, and E-Cell window seals at a constant dose rate of $3,500 \mathrm{R} / \mathrm{hr}$ is tabulated in Figure $\mathrm{F} 1$ and shown graphically in Figure F4. The leaded window seals, Koroseal 116 , were only good for 3.26 years or until about 1988. The cerium window seals are good for 32.62 years or until about 2018. Obviously, the leaded windows in these cells have been in jeopardy of failure for some time and could possibly fail at any time. The cerium window seals in these cells may be serviceable for some time. However, other factors such as temperature cycling, humidity, 
improper storage or installation of the seal material could have reduced the effective life of these seals.

4. F-Cell window seals have experienced and continue to experience extremely high radiation dose rates from the three cesium capsules being stored in it. The theoretical seal life expired in mid-1996 as shown in Figure F5. Appendix B. Because the radiation sources can be defined, the seal dose accumulation values should also be reasonably accurate. The result of the caiculations shows the actual received dosage for all the seals is higher than the limit of both seal materials used in the cell window. In particular, the leaded window seals which are Koroseal 116 have been severely overexposed to radiation and probably retain very little of the materials original properties which allow it to function as a seal. Any window can fail at any time and it is probable that more window seals will fail in the near future. Some of the overexposed cerium window seals may have already failed and may not be capable of functioning properly as air seal should the leaded windows be removed.

The oil in the window has a dosage limitation of $1 \times 10^{8} \mathrm{R}$, similar to the Koroseal material. If the oil in the leaded windows has not been changed since the 1985 refurbishment, then it also has deteriorated and may be causing damage to the glass surfaces.

5. G-Cell processed capsules returned from commercial use. The window seals experienced a total radiation dose of $1.31 \times 10^{8}$. This is illustrated by a curve in Figure F4, Appendix B. The total accumulated dose for the cerium windows is less than the maximum allowable for a Adiprene seal. However the leaded window seals have been overexposed and are in risk of failure at any time. Refurbishment both of the leaded windows should be performed if the cell is to continue as a functioning hot cell or a laid-up hot cell. Any additional radiation exposure in the cell should be limited to protect the seals.

\section{RECOMMENDATIONS}

FDNW recommends that the following actions be taken by WESF to minimize radioactive waste in the hot cells and allow for the lay-up of A-through E-Cells and allow for the continued use of G-Cell and F-Cell:

- Priority 1: Remove the cesium capsules in F-Cell or provide adequate shielding to make radiation effects minimal. 
- Priority 2: Replace the seals in F-Cell cerium window.

- $\quad$ Priority 3: Refurbish the C-Cell leaded window.

- $\quad$ Priority 4: Refurbish the F-Cell leaded window.

- $\quad$ Priority 5: Refurbish both G-Cell leaded windows.

- $\quad$ Priority 6: Refurbish the remaining leaded windows.

- All of the work should be completed as soon as possible but at least within the next two to three years.

The priorities recommended by FDNW may be modified by WESF to reflect other operation and maintenance concerns not known or considered as part of the scope of this report.

\section{$X$ REFERENCES}

A. DOCUMENTS

(Note: References to documents exist in Appendix B, Radiation Calculations and Figures. These references are listed within the appendix.)

\section{B. CORRESPONDENCE}

1. Letter of Instruction 2C-96-036-01, F. H. Lee to W. A. Holstein, October 22, 1996, "Waste Encapsulation and Storage Facility Decoupling Project, Waste Minimization Activities," Subject: Basic scope of work for this report.

2. Letter of Instruction 2C-96-036-02, F. H. Lee to W. A. Holstein, December 6, 1996, "Waste Encapsulation and Storage Facility Decoupling Project, Waste Minimization Activities," Subject: Revision to original LOI adding F-Cell and G-Cell and deleting fire protection system.

3. Supporting Document SD-WM-ER-013, "WESF E-Cell Cerium Coverglass Changeout," Rockwell Hanford Operations, November 1, 1984. 







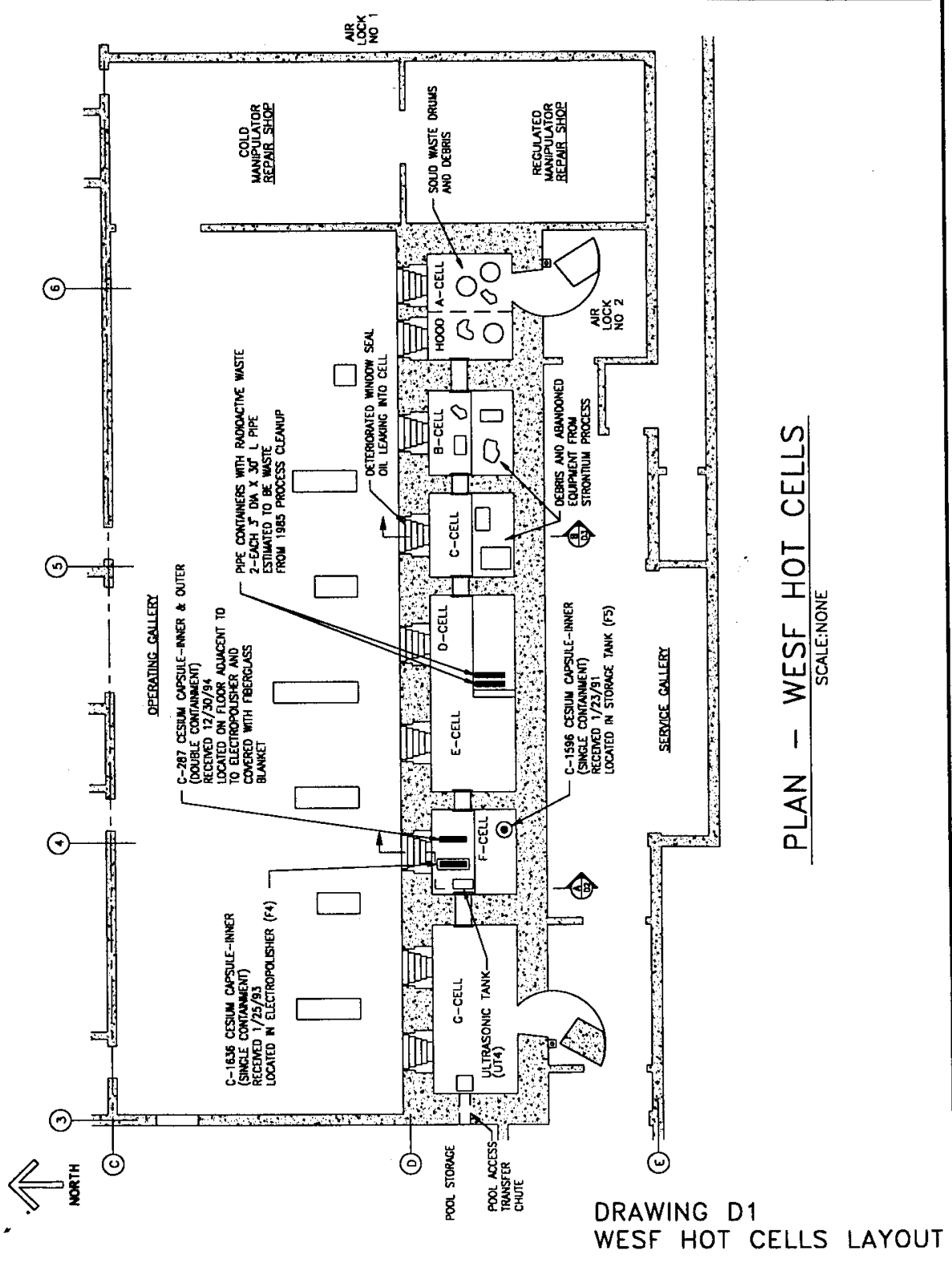




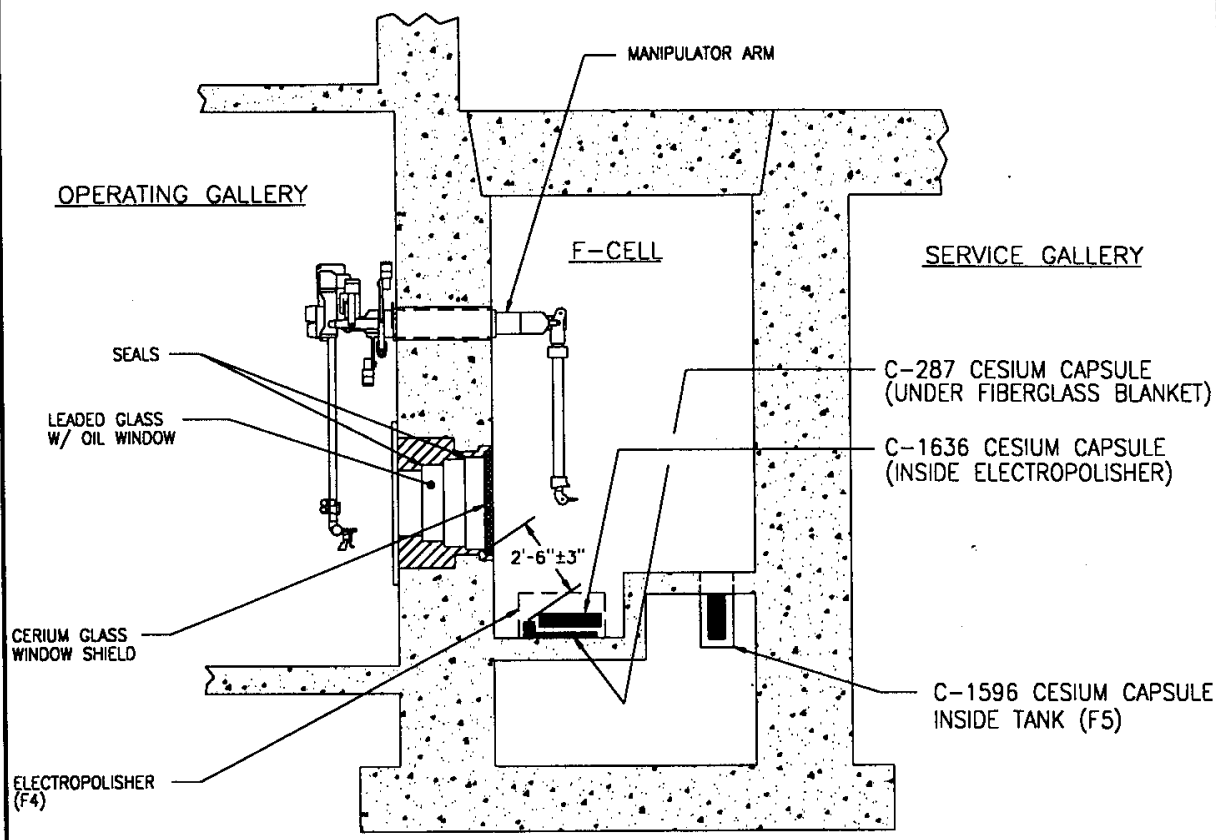

(A) SECTION $-F-C E L L$

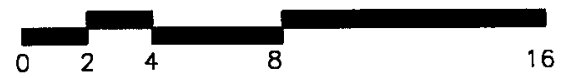

DRAWING D2 F-CELL SECTION 


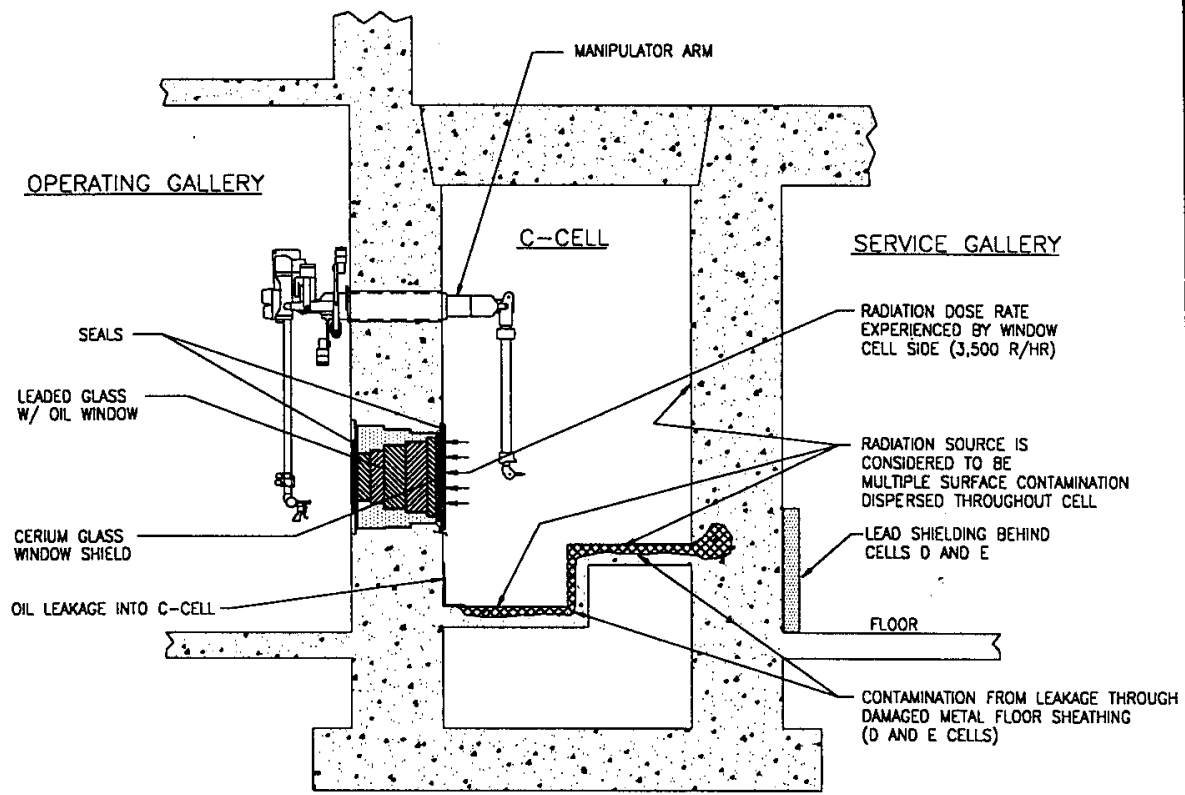

(B) SECTION - C-CELL

TYPICAL FOR CELLS $B, D \& E$

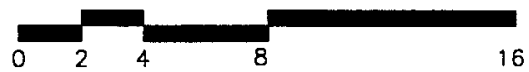

DRAWING D3

C-CELL SECTION 


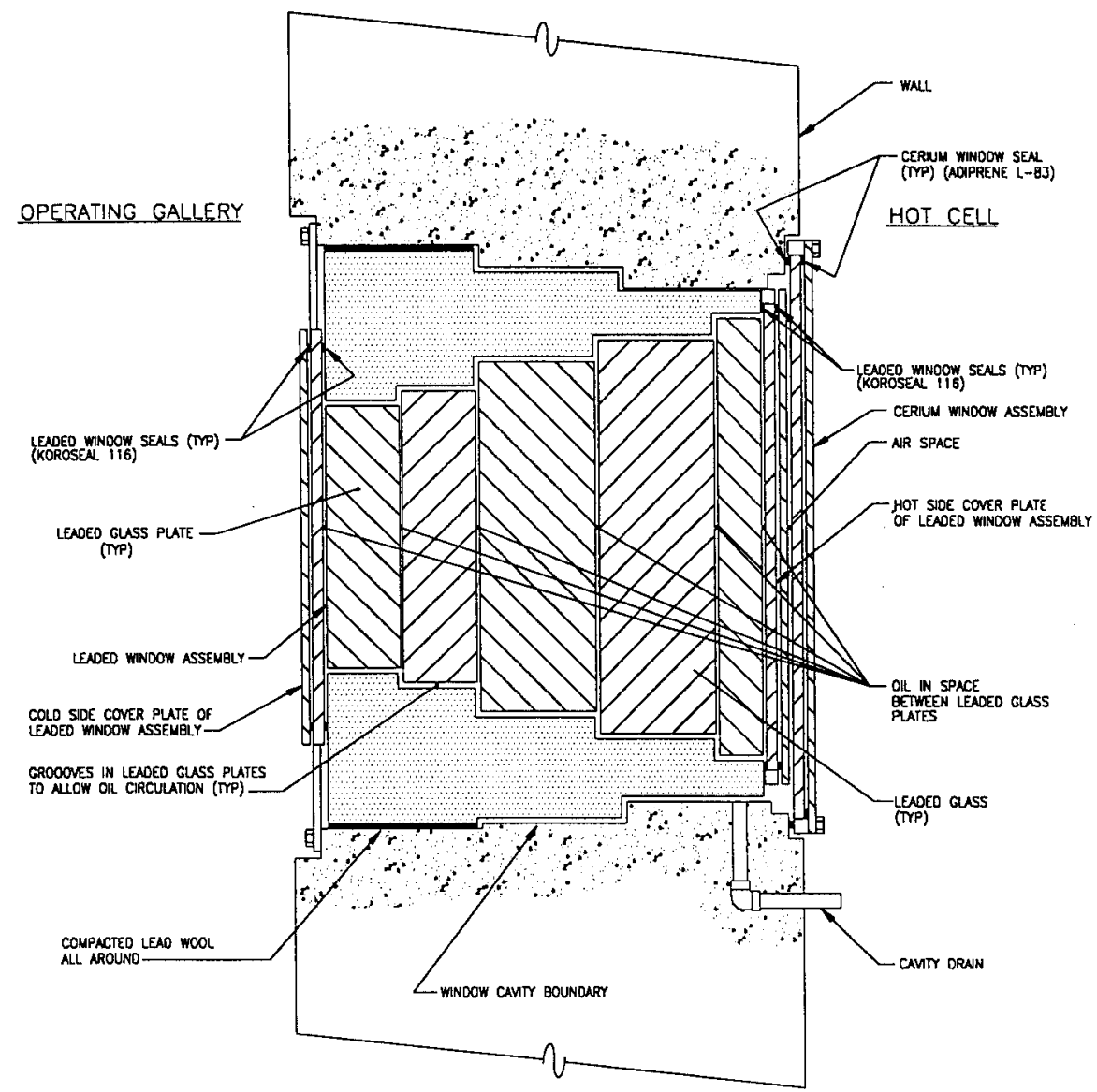

DRAWING D4

TYPICAL WINDOW SECTION 


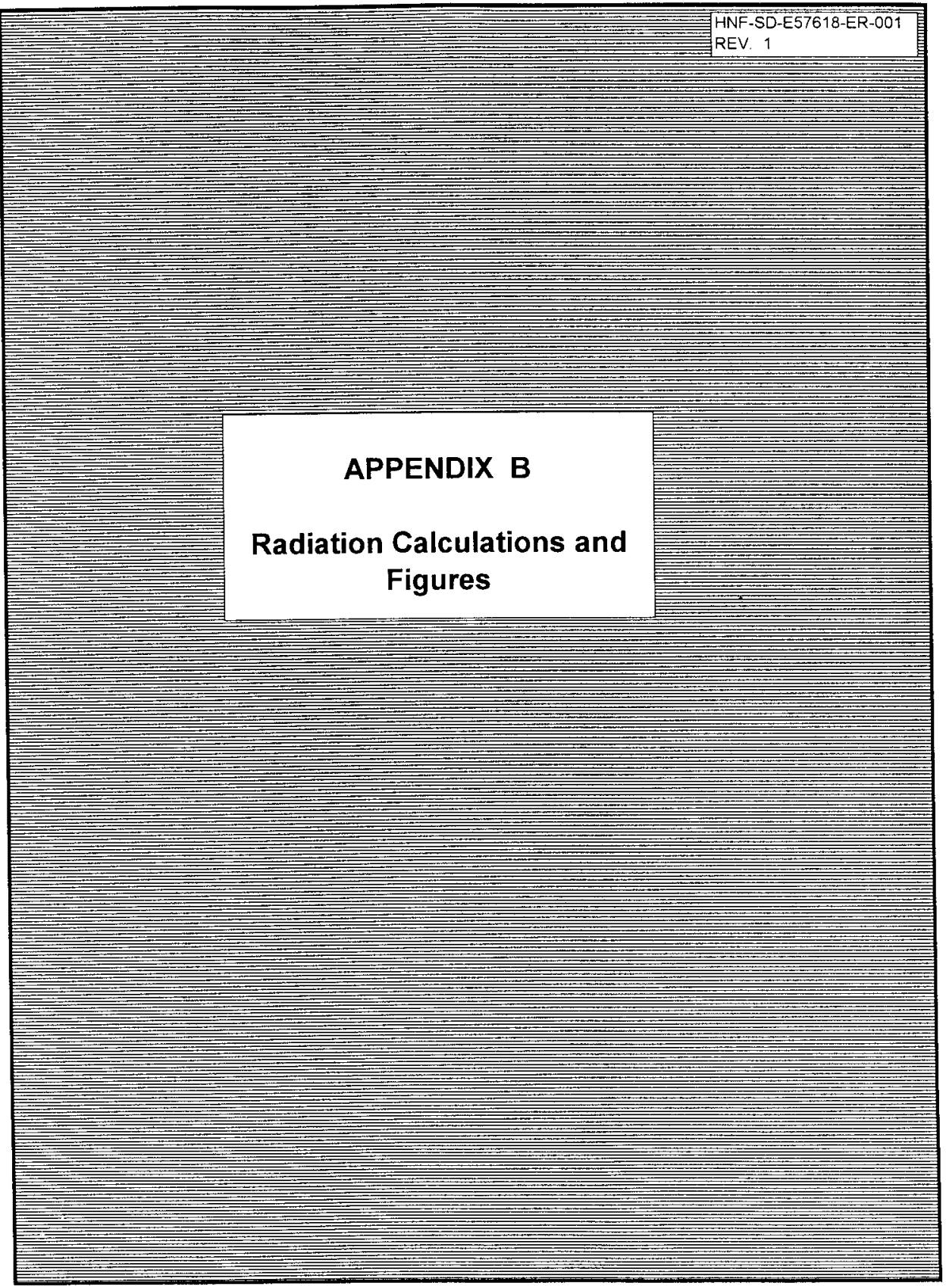


BY: Charles T. Li

DATE: $\quad$ March 19, 1997

\section{OBJECTIVE:}

Determine dose rates from Cesium and Strontium capsules of WESF, and use the calculated and measured data to evaluate the severity of the radiation damage of the hot cell window seal material from a given source. Determine the radiation damage to seal material due to exposure to surface contamination based on a given dose rate.

\section{DESIGN INPUTS:}

\section{Criteria \& Source:}

- Seal (gasket) material of the hot cell cerium windows are Adiprene L-83 (Uniroyal) having maximum allowable radiation dosage limit of $1 \mathrm{x}$ $10^{9} \mathrm{R}$. The leaded glass windows were constructed utilizing Koroseal 116 for the seal materia\}. Koroseal 116 is estimated to have a maximum allowable radiation dosage limit of $1 \times 10^{8} \mathrm{R}$. WESF staff who were present when the windows were last refurbished concur with hot Cell Services, Inc. (HCS) who performed most of the leaded window refurbishment work that the seal materials stated above were installed. The radiation dosage limit for Adiprene L-83 are stated in the manufacturer's literature included in Appendix E, Seal Material Specifications. The radiation dosage limit for Koroseal 116 could not be provided by the manufacturer since it is not included in the manufacturer's specification. However, HCS, who has evaluated the material in the past for use in radioactive environments, estimates the 1 imit to be $1 \times 10^{8} \mathrm{R}$. When the cumulative dosage received by the seal is higher than the allowable value of the seal material, the seal will start to deteriorate, and the integrity of the window system becomes questionable.

Given / Known Data:

- Theoretical design activities and dimensions of original capsules are given in R. R. Jackson's paper, "Hanford Waste Encapsulation: Strontium and Cesium," Nuclear Technology Volume 32, January 1977.

- The maximum allowable radiation dosages were obtained as vender information (URA-RAD from Hot Cell Services Corporation and Adiprene L-83 from Dupont, assuming they are one in the same material).

- The measured dose rate in cell $B, C, D$, and $E$ is assumed to be 3,500 $\mathrm{R} / \mathrm{hr}$ and the measured dose rate in cell $\mathrm{A}$ is assumed to be $100 \mathrm{R} / \mathrm{hr}$ per the January 2, 1997 ccMail from Mario Pereira, WESF.

- The decay corrected activity data of the three cesium capsules in FCell were provided from Karen Bender via ccmail to Karl Walterskirchen, $2 / 28 / 97$, which are the following values:

- The numbers of capsules returned through G-Cel1, 775 cesium and 4 strontium, were provided by Karen Bender of WESF via ccMail to Karl 
Walterskirchen, 3/19/97, with confirmation via ccMajl by Mario Pereira.

\section{Assumptions:}

- Radiation source will be uniformly distributed in the capsule.

- The capsule will be modeled as Cylindrical Source - Cylindrical Shields (IGEOM $=7$ in ISOSHLD computer code).

- The surface contamination dose rates, $100 \mathrm{R} / \mathrm{hr}$ for $\mathrm{A}-\mathrm{Cel} 1$ and 3,500 $\mathrm{R} / \mathrm{hr}$ for $\mathrm{B}$ - through $\mathrm{E}-\mathrm{Ce} \mathrm{ll}$, are radiation levels experienced by the seals closest to the hot side of the cell which are the perimeter seals around the edge of the cerium widows. It is assumed that the seals in the hot side cover plate of the leaded windows experience the same dose rate since the cerium window offers very little radiation protection.

Method Used:

- ISO-PC version 1.98 will be used for dose rate calculations.

\section{References:}

1. R. R. Jackson, "Hanford Waste Encapsulation: Strontium and Cesium," Nuclear Technology Vol. 32 January 1977.

2. WESF E-Ce11 Cesium Coverglass Changeout, SD-WM-ER-013, by Elizabeth K. Carter, page 23 and pages 35 and 36 of Appendix I.

3. Radiation Resistant Gaskets, URA-RAD, Hot Cell Services Corporation, 22526 85th Place South, Kent, WA 98031, (206)854-4945, Fax (206)854-4947.

4. CCMail from Mario Pereira to K. M. Waiterskirchen, 1/2/97.

5. CcMail from Karen Bender to K. M. Walterskirchen, $2 / 28 / 97$.

6. CcMail from Karen Bender and Mario Pereira to K. M. Walterskirchen, $3 / 19 / 97$. 


\section{CALCULATIONS:}

Information listed in Figure 2 of Reference 1 were used as the input data for the ISOSH computer code. Density of strontium fiuoride and cesium chloride are given a percent of theoretical density of 68 and 65 , respectively, based on total void space of capsule.

The theoretical densities from Lange's Handbook of Chemistry are 4.24 and 3.988 , respectively, for strontium fluoride and cesium chloride. The true densities to be used in the computer code are as follows.

Strontium Fluoride : $4.24 \times 0.68=2.8832$

Cesium Chloride : $3.988 \times 0.65=2.59$

IGEOM $=7$, Cylindrical source - Cylindrical shields, of ISOSHLD were used for modeling.

Results:

Dose Rates obtained from these calculations are as follows (Computer outputs of ISOSHLD calculation can be seen in Figure Fl):

\begin{tabular}{ccc} 
Distance, ft & $\begin{array}{c}\text { Cs-capsule } \\
\text { Rr/hr }\end{array}$ & $\begin{array}{c}\text { Sr-capsule } \\
\text { R/hr }\end{array}$ \\
\cline { 2 - 3 } 1 & $1.86 \mathrm{E}+05$ & $5.40 \mathrm{E}+03$ \\
2 & $5.65 \mathrm{E}+04$ & $1.66 \mathrm{E}+03$ \\
3 & $2.64 \mathrm{E}+04$ & $7.79 \mathrm{E}+02$ \\
4 & $1.52 \mathrm{E}+04$ & $4.48 \mathrm{E}+02$ \\
5 & $9.82 \mathrm{E}+03$ & $2.90 \mathrm{E}+02$ \\
6 & $6.87 \mathrm{E}+03$ & $2.03 \mathrm{E}+02$ \\
7 & $5.07 \mathrm{E}+03$ & $1.50 \mathrm{E}+02$
\end{tabular}

Dose rates versus Distance from Surface of Capsule are given in Figures F2 and $\mathrm{F} 3$ for Cesium Chloride and Strontium Fluoride respectively.

If seal material with a $1 \times 10^{9} \mathrm{R}$ maximum allowabie dosage value is exposed to the above capsules, the service life of the seal material is calculated in years per distance from the source as follow:

\begin{tabular}{ccc}
$\begin{array}{c}\text { Distance } \\
\mathrm{ft}\end{array}$ & $\begin{array}{c}\text { Exposed to Cs-capsuTe } \\
\text { years }\end{array}$ & $\begin{array}{c}\text { Exposed to Sr-capsule } \\
\text { years }\end{array}$ \\
\cline { 2 - 3 } 1 & 0.63 & 21.66 \\
2 & 2.07 & 70.46 \\
3 & 4.43 & 150.30 \\
4 & 7.72 & 261.31 \\
5 & 11.92 & 403.73 \\
6 & 17.05 & 577.41 \\
7 & 23.10 & 782.88
\end{tabular}


FINDINGS AND CONCLUSIONS:

Seal deterioration from surface contamination:

A-Cel1:

A-Cell Window received very little radiation based on the $100 \mathrm{R} / \mathrm{hr}$ value provided (Ref. 4). We conclude that The A-Cell seals received negligible radiation damage and will not be a factor in considering the cell for "laidup" status. This does not preclude seal failure for other reasons which will be discussed below.

B-Cell, C-Cell, D-Cell and E-Cell:

Cells $B, C, D$, and $E$ have a measured dose rate of $3500 \mathrm{R} / \mathrm{hr}$ (in an average) (Ref. 4). The possible service life of the cerium window seal material used for these cells is:

\section{$1 \times 10^{9} \mathrm{R} / 3500 \mathrm{R} / \mathrm{hr} / 24 \mathrm{hr} /$ day $/ 365 \mathrm{day} /$ year $=32.62$ years}

The possible service life of the leaded window seal material used for these cells is

$$
1 \times 10^{8} \mathrm{R} / 3500 \mathrm{R} / \mathrm{hr} / 24 \mathrm{hr} / \text { day } / 365 \text { day } / \text { year }=3.26 \text { years }
$$

These calculations are based on an assumptions that dose rate is constant and was received from the first day of the cell operation. If the last refurbishment of these cells took place in 1985, approximately 12 years have passed by. The leaded window seals, Koroseal 116, were only good for 3.26 years or until about 1988. The cerium window seals are good for 32.62 years or until about 2018. Obviously, the leaded windows in these cells have been in jeopardy of failure for some time and could possibly fail at any time. The cerium window seals in these cells may be serviceable for some time. However, other factors such as temperature cycling, humidity, improper storage or installation of the seal material could have reduced the effective life of these seals.

At the present time, C-Cell can hold oil up to about one-half of the height of the window. This means that the leaking point (or points) must be located on the side and at or higher than the current oil level of the window. The cause of the failure is not known, however, it is likely the result of radiation deterioration of the seal materials with the excessive overexposure.

A material specification sheet for Cast Sheet, Polyurethane, Polyether, was received from WESF and is included in Appendix $E$ or this report. It stated that "The gasket material shall be a one piece sheet of cast polyurethane, with a nuclear radiation tolerance of $1 \times 10^{8} \mathrm{R}$ total dose and a Shore $A$ hardness of 82." It is believed that this specification was used for the procurement of the Koroseal 116 which has a much lower radiation resistance value. Figure $\mathrm{F} 4$ shows the service life of both materials, one with $1 \times 10^{9}$ $\mathrm{R}$ value and one with $1 \times 10^{8} \mathrm{R}$ value.

The cumulative dosages vs. time for window seals in Cells $B, C, D$ and $E$ are shown in Figure F4. 
Seal deterioration from point source radiation (capsules):

The dose rate of cesium (Cs) capsules are much higher than the strontium $(\mathrm{Sr})$ capsules as shown in Figure $\mathrm{Fl}$. Therefore, the radiation damage to the seal material from Cs-capsule is more severe than Sr-capsule.

F-Ce]1:

In $F$ cell there are a capsule placed 7 feet from the window since January 1991 , a capsule 2.5 feet from the window since January 1993 and a capsule 2.5 feet from the window. All of them are Cs-capsule. The cumulative dosage (from Jan. 1991 to Jan. 1997) can be calculated using a constant dose rate model as following.

$\{5.07 E+03 \times(1997-1991)+4.15 E+04 \times(1997-1993)+4.15 E+04 \times(1997-1995)\}$ $\times 24 \times 365=2.45 E+09 R$

Figure 4 is a plot of Cumulative Dose vs Year of $F$ cell. It shows that the capsule, which was placed at 2'- 6" from the window in 1993, is the major dose contributor. Note that the above calculation is based on the original capsule activity of $70000 \mathrm{Ci}$ at a constant dose rate, therefore the cumulative dosage of $2.45 E+09 R$ could be higher than the actual value.

Calculated decayed activity values and of capsules decayed to $3 / 1 / 97$ (Ref. 5 ) and the storage periods of each capsule in $\mathrm{F}-\mathrm{Ce} 11$ are given in the following table:

$\begin{array}{llrc}\begin{array}{c}\text { Capsule } \\ \text { ID }\end{array} & \begin{array}{c}\text { Activity as of } \\ \frac{3 / 1 / 97}{1596}\end{array} & \begin{array}{c}\text { Storage } \\ \text { Date }\end{array} & \begin{array}{c}\text { Decay Period } \\ \text { (years) }\end{array} \\ C-17.82 \mathrm{KCi} & \frac{1 / 23 / 91}{1 / 25 / 93} & 6.11 \\ \mathrm{C}-1636 & 35.87 \mathrm{KCi} & 12 / 30 / 94 & 4.10 \\ \mathrm{C}-287 & 39.12 \mathrm{KCi} & 17\end{array}$

Based on these information, the activity at the date the capsules being placed into the cell can be calculated by the following equation:

$$
\text { Where } \begin{aligned}
\alpha_{0} & =\alpha(t) / \exp \left(-0.693 / T_{1 / 2} \times t\right) \\
\alpha_{0} & =\text { Initial activity at time zero, } C i \\
\alpha(t) & =\text { Activity at time } t, C i \\
T_{1 / 2} & =\text { Half life of } C s-137,30.17 \text { yrs } \\
t^{1 / 2} & \text { Decay time, yrs }
\end{aligned}
$$

The resulting initial activities on the date they were placed in the cell are

$$
\begin{array}{ll}
\mathrm{C}-1596 & 43516.54 \mathrm{Ci} \\
\mathrm{C}-1636 & 39411.84 \mathrm{Ci} \\
\mathrm{C}-287 & 41119.64 \mathrm{Ci}
\end{array}
$$

Since the dose rate is direct proportional to the activity, the dose rate generated in Figure 1 of this appendix, based on the initial activity of $70000 \mathrm{Ci}$, can be used to calculated the initial dose rates of these capsules.

$$
\begin{aligned}
\mathrm{C}-1596: & 5.07 \times 10^{3} \mathrm{R} / \mathrm{hr} \times 43493.04 \mathrm{Ci} / 70000 \mathrm{Ci}=3.15 \times 10^{3} \mathrm{R} / \mathrm{hr} \\
\mathrm{C}-1636: & (5.65+2.64) \times 10^{4} / 2 \mathrm{R} / \mathrm{hr} \times 39397.99 \mathrm{Ci} / 70000 \mathrm{Ci} \\
& =2.33 \times 10^{4} \mathrm{R} / \mathrm{hr}
\end{aligned}
$$




$$
\text { C-287: } \quad \begin{aligned}
(5.65+2.64) \times 10^{4} / 2 \mathrm{R} / \mathrm{hr} \times 41195.41 \mathrm{Ci} / & 70000 \mathrm{Ci} \\
& =2.43 \times 10^{4} \mathrm{R} / \mathrm{hr}
\end{aligned}
$$

The dose rate decreases with time following the exponential equation as in the decrease of activity with time. Therefore, the dose rate as function of time can be written as

$$
\text { Dose } \operatorname{rate}(t)=\text { Dose } \operatorname{rate}(0) \times \exp \left[\left(-0.693 / T_{1 / 2}\right) \times t\right]
$$

Where

Dose rate(t) is dose rate at time $t, R / h r$

Dose rate $(0)$ is dose rate at time zero, $R / \mathrm{hr}$

By integrating the above equation with respect to time, the cumulative dosage can be obtained as

$$
\begin{array}{ll}
\text { Cumulative dosage }= & \text { Dose rate }(0) /\left(-0.693 / \mathrm{T}_{1 / 2}\right) \times \\
& \left\{\exp \left[\left(-0.639 / \mathrm{T}_{1 / 2}\right) \times \mathrm{t}\right]-Y\right\}
\end{array}
$$

From this equation we obtained the cumulative dosage contributed by each capsule as
$\mathrm{C}-1596$
C-1636
C-287
$1.57 \times 10^{8} \mathrm{R}$
$8.00 \times 10^{8} \mathrm{R}$
$4.51 \times 10^{8} \mathrm{R}$

Total Cumulative Dosage for F-Cell window seals from $1 / 23 / 91$ to $3 / 1 / 97$ :

$$
\begin{aligned}
& =1.41 \times 10^{9}>1 \times 10^{9} \mathrm{R} \text { (Adiprene } \mathrm{L}-83 \text { ) } \\
& =\quad 1.41 \times 10^{9}>1 \times 10^{8} \mathrm{R} \text { (Koroseal } 116 \text { ) }
\end{aligned}
$$

Figure $F 5$ shows the comparison of cumulative dosage of F-Cell based on a constant dose rate and a decaying dose rate. The result of the latter calculation is closer to the actual received dosage. However, the cumulative dosage is still higher than the limit of both seal materials used in the cell window. In particular the leaded window seals which are Koroseal 116 have been severely overexposed to radiation and probably retain very little of the materials original properties which allow it to function as a seal. It is probable that more window seals will fail in the near future and any window can fail at any time. Some of the overexposed cerium window seals may have already failed and may not be capable of functioning properly as air seal should the leaded windows be removed.

It should also, be note that the oil in the window has a dosage limitation of $1 \times 10^{8} \mathrm{R}$, similar to the Koroseal material. If the oil in the leaded windows has not been changed since the 1985 refurbishment then it also has deteriorated and may be causing damage to the glass surfaces and cloudiness in the oil.

G-Cel1:

Data 27 so show that $G$ cell was use for transfer and/or inspection of capsules to be stored in the pool. Record shows that a total of 775 Cscapsules and 4 Sr-capsules (Ref. 6) have been transferred and/or inspected in the cell. If inspection is done by holding capsules two feet from the inside surface of the window (or from the seal material), and inspection 
take three hours per capsule, the total dosage received by the seal material can be calculated as

$$
775 \times 3 \times 5.65 \times 10^{4}+4 \times 3 \times 1.66 \times 10^{3}=1.31 \times 10^{8} \mathrm{R}
$$

$\begin{array}{ccc}\text { which shows that.. } & 1.31 \times 10^{8} \mathrm{R} \ldots \text { is.. } & <1 \times 10^{9} \mathrm{R} \text { (Adiprene } \mathrm{L}-83 \text { ) } \\ \text { but... } & 1.31 \times 10^{8} \mathrm{R} \ldots \text { is.. } & >1 \times 10^{8} \mathrm{R} \text { (Korosea) 116) }\end{array}$

According to this calculation the cerium window seal material for G-Cell may still be good but the leaded window seal limit has been exceeded. The cumulative dosage vs time for G-Cell is also plotted in Figure F4.

Data of the maximum allowable dosage a material given by the vendors are usually based on statistical analyses of their laboratory data obtained from accelerated dose exposure experiments using dose rates higher than commoniy encountered in the actual situations.

There are so many uncertainties involved in this evaluation. That is why the sudden failure of $\mathrm{C}$ cell window with lower than the maximum allowable dosage, and no problem in $F$ cell with higher than the maximum allowable dosage could happen. 


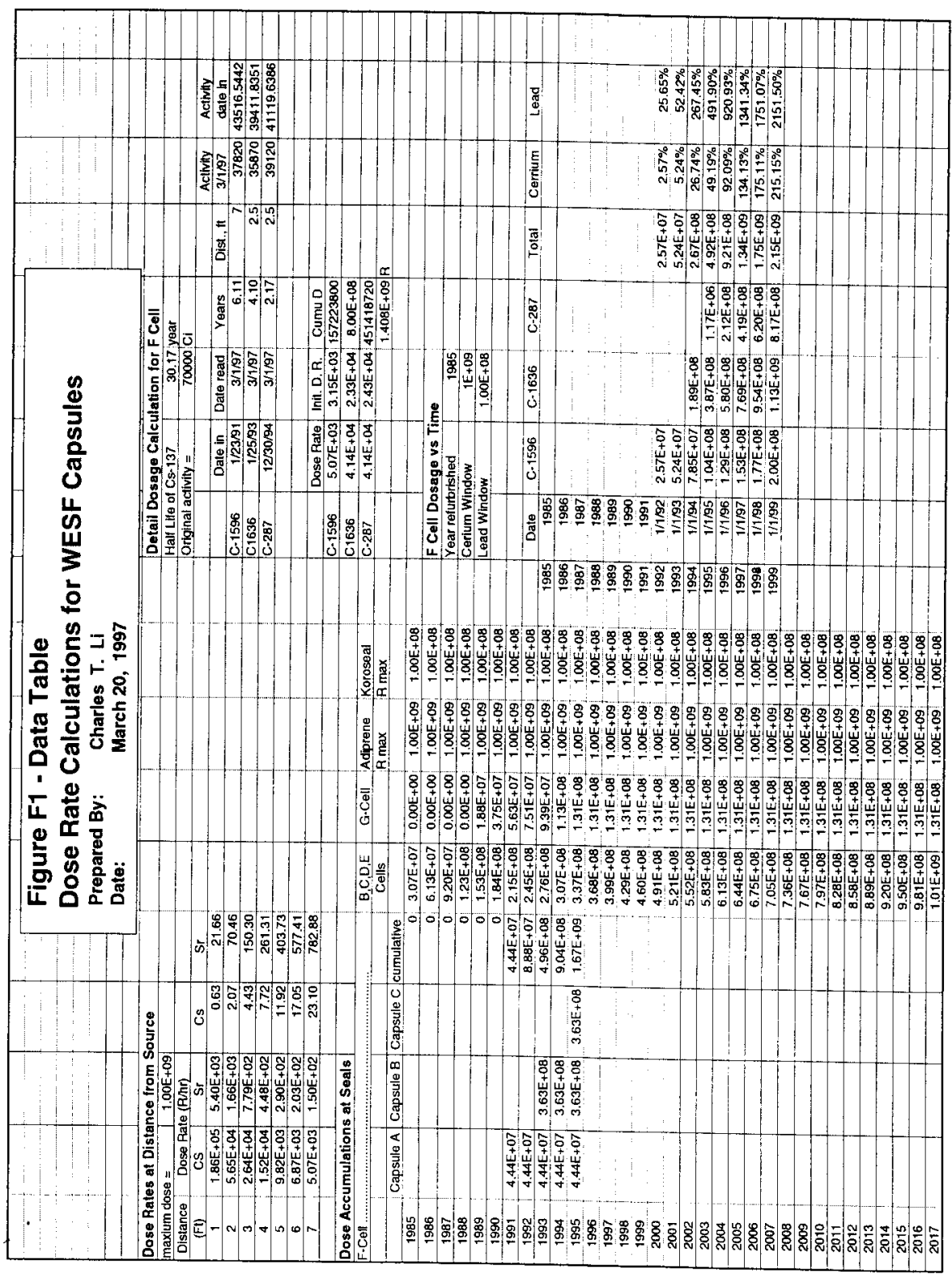


Figure F2 - Dose Rate from Typical

Cs-capsules (@ original activity level)

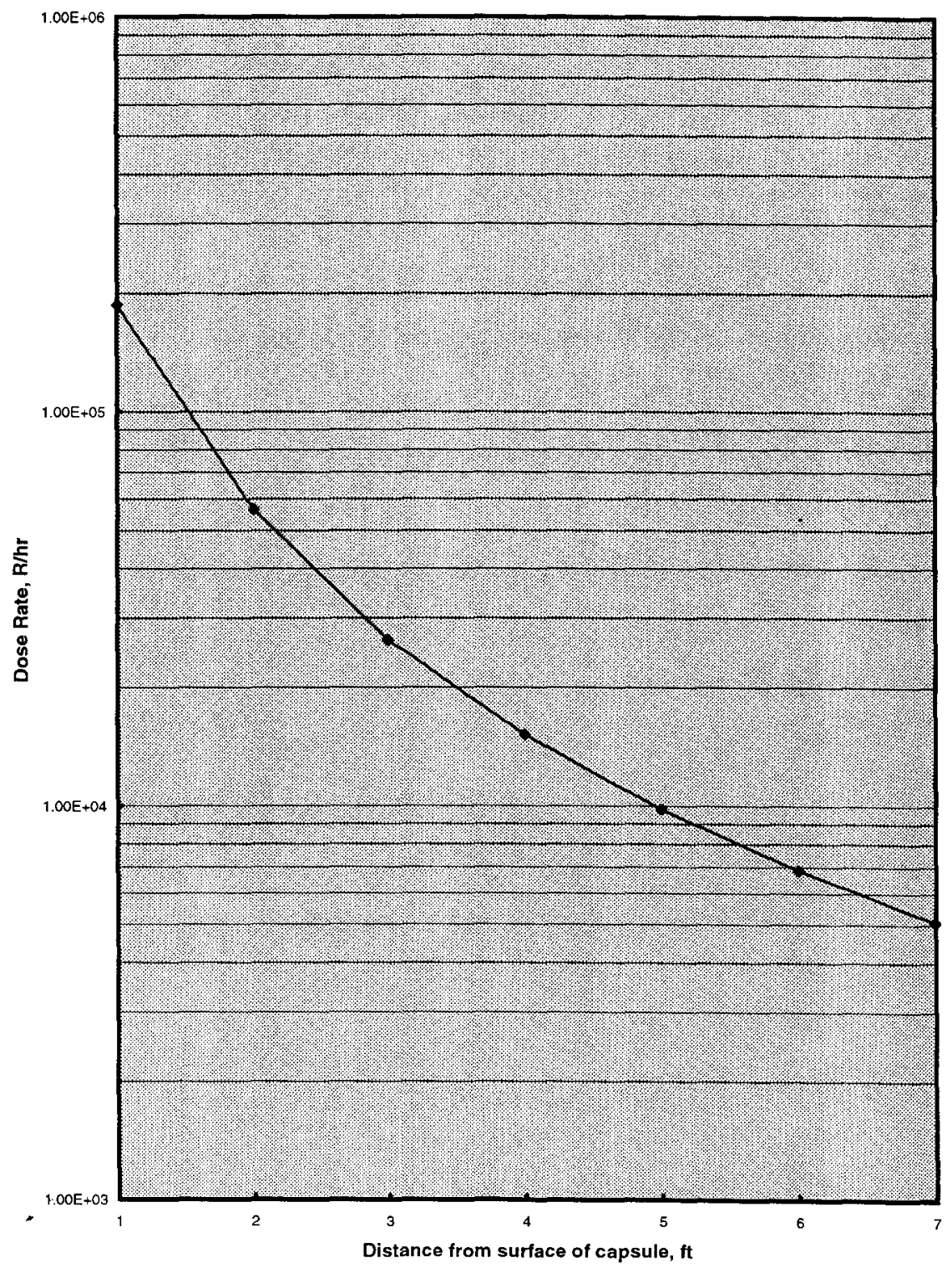


Figure F3 - Dose Rate from a Typical

Sr-capsule (@ original activity level)

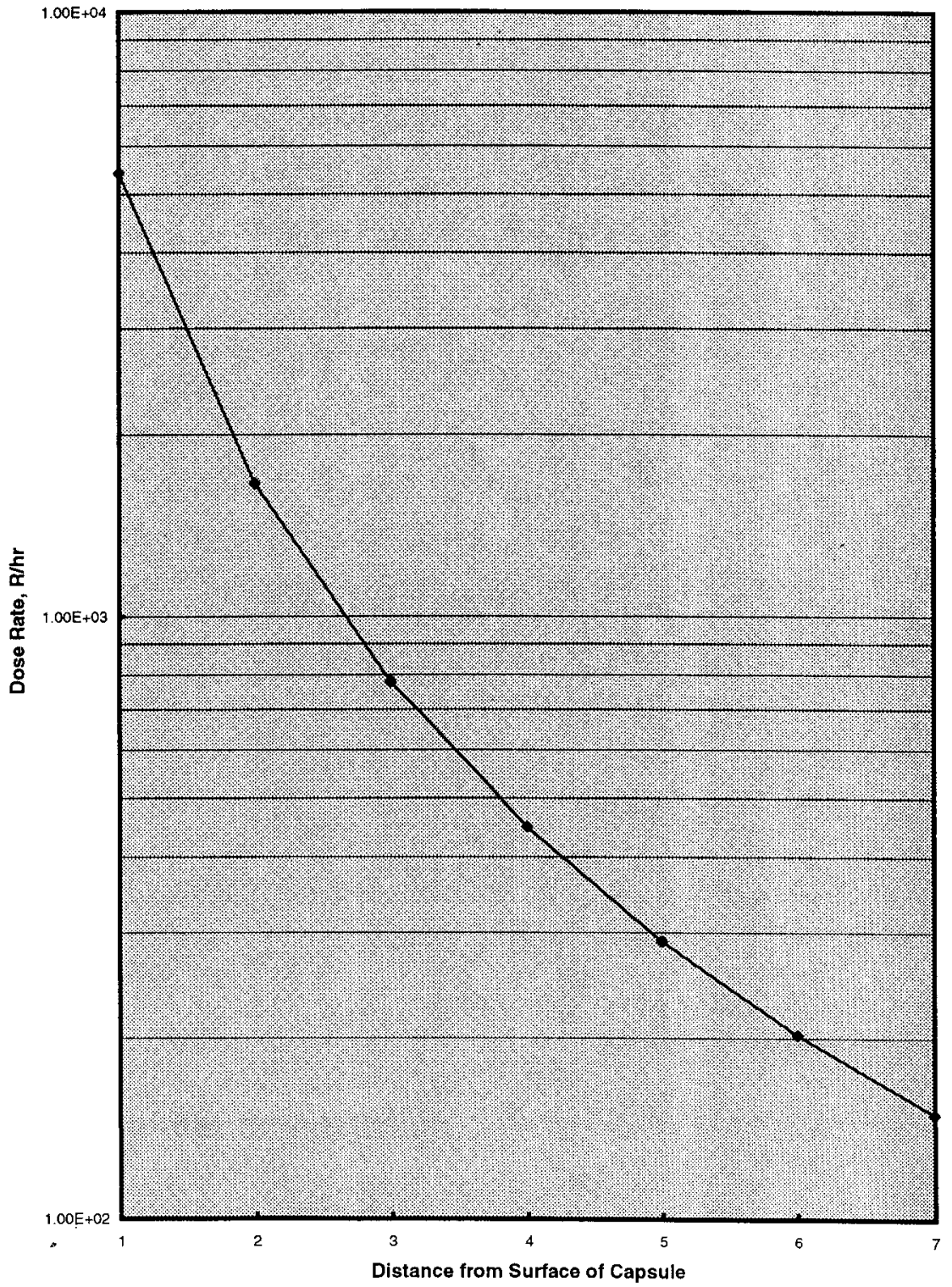


Figure F4 - Cumulative Seal Dose vs Time of Exposure in B, C, D, E, F and $G$ Cell of WESF

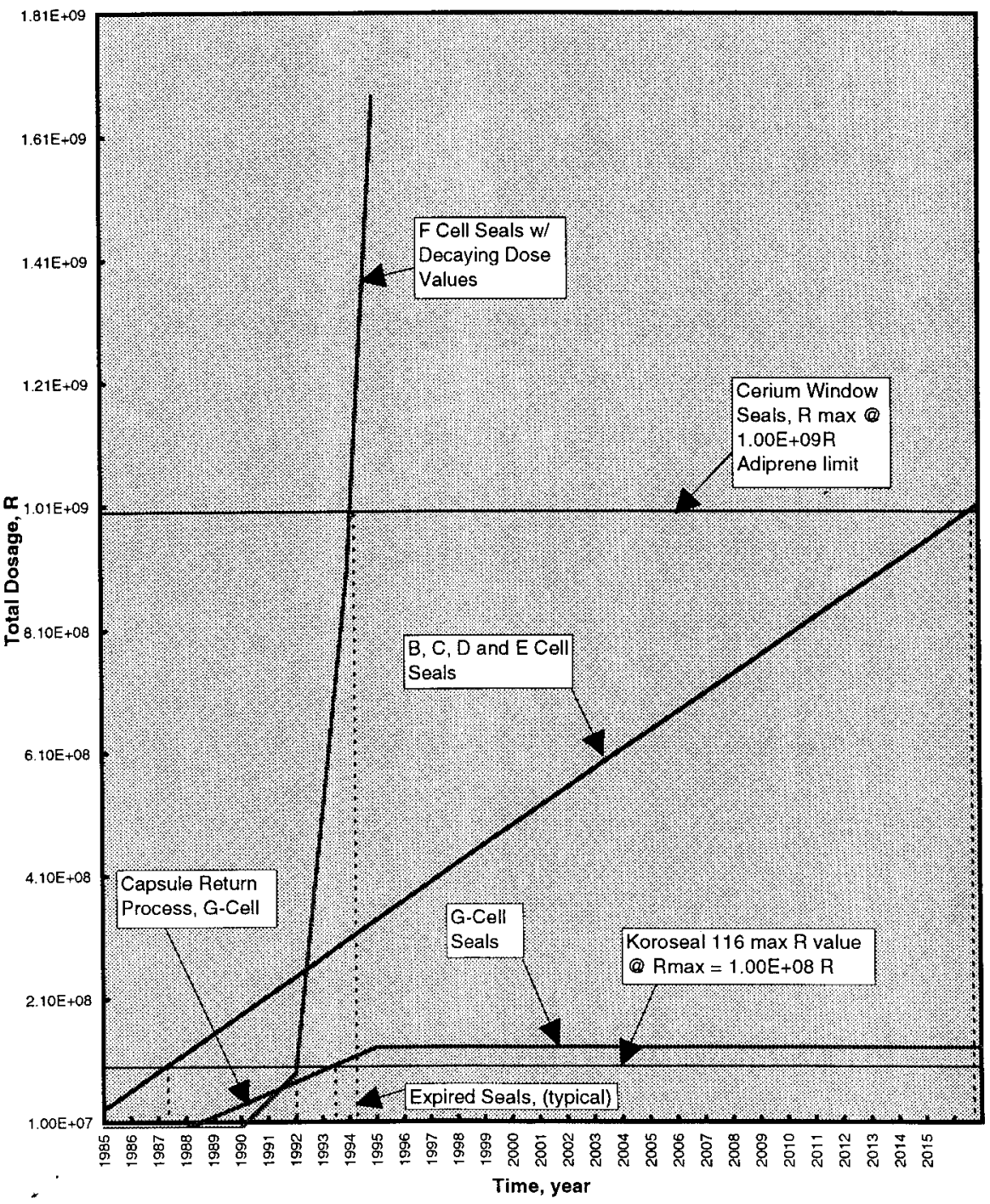


Figure F5 - Cumulative Seal Dose vs Time of Exposure for F-Cell Seals

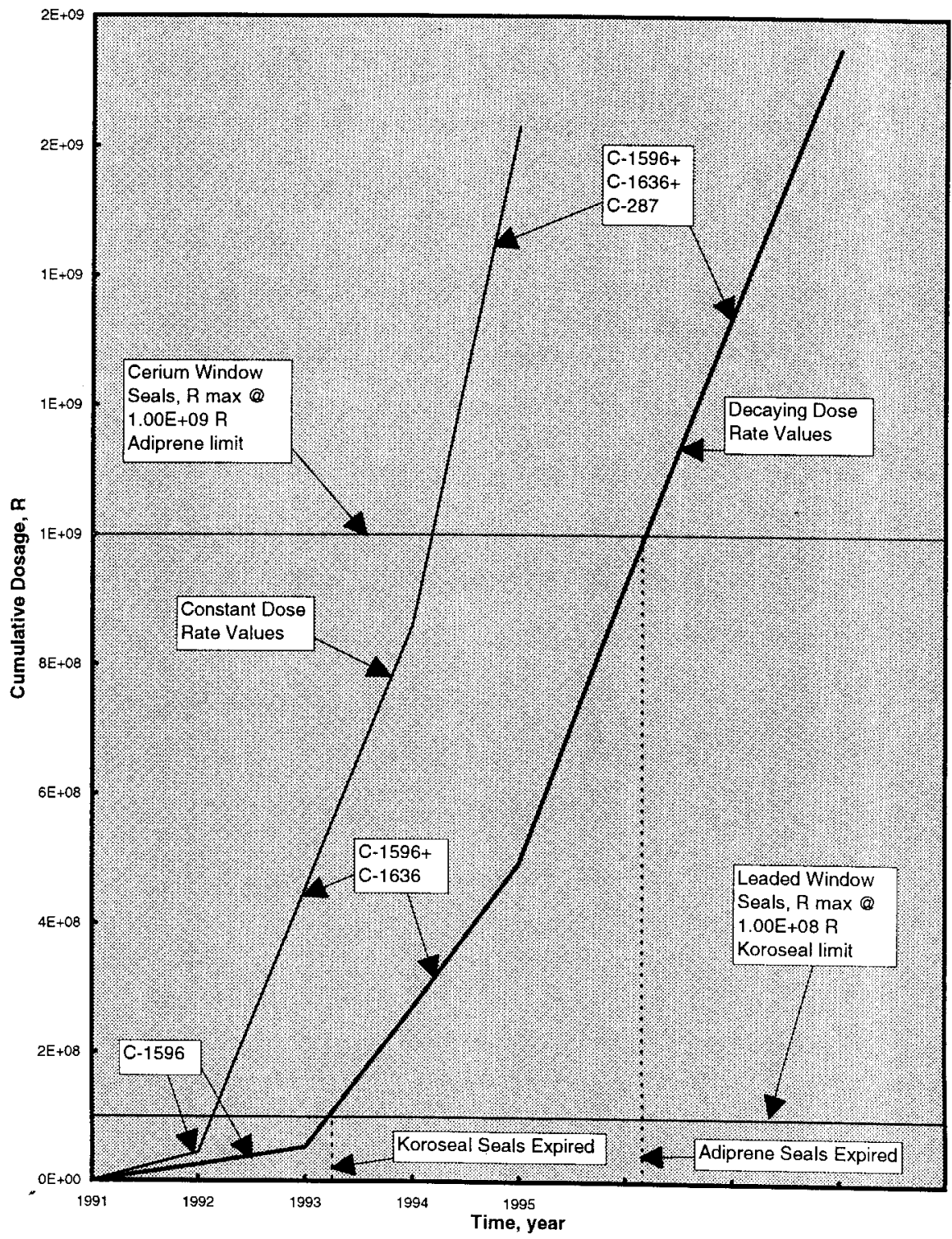




\section{APPENDIX C}

\section{Data Collection Log}




\section{APPENDIX C}

\section{DATA COLLECTION LOG}
REVISION:
02
PROJECT:
WESF Hot Cells Criteria
DATE: January 10,1996
TO:
C. R. Zook
FROM:
K. M. Walterskirchen

\section{STATUS}

1. Hot Cell Services (HCS): I received a spec data sheet from HCS on Ura-Rad, the current state-of-the-art hot cell window seal material. Its maximum radiation exposure limit is quoted at 10 9 rad. There was no shelf life quoted. I called Ron Campbell back. He was reluctant to quote anything but he would check. I then received a call from Dave DaGrava at HCS who stated the shelf life of Ura-Rad is from 7 months to 1 year if the material is stored at $50-70^{\circ} \mathrm{F}$ and low humidity. This, of course, was preinstallation actual "shelf" life. I explained I needed to know what life they could predict after installation but without radiation exposure. He said that depends on the type of installation and environment. Oil filled windows are best for preserving the material. The seal surfaces exposed to air will degrade faster. They cannot give us any figures for this and he will send me a fax restating the information given over the phone. The fax was received. See sub-attachment B.1.

DaGrava did mention HCS had just shipped four rolls of Ura-Rad to Hanford within the last month. He did not know where it was going but remembered the shipping/receiving agent was Alice (?). I tracked her down through Central Warehousing as Alice Hendrickson. Alice confirmed the seal material is in the warehouse waiting for Mike Hill (WESF QA) to approve it. Larry Nunn is to receive it. The cost for the material is $\$ 735$ at 4 each, total @ $\$ 2,940$. DaGrava said it was a substantial amount of material but did not know how many windows it would serve.

I faxed Dave DaGrava a request for additional clarification on the compounding effect of Ura-Rad. Don Alexander from HCS faxed me a copy of a letter from Chalk River Laboratories to HCS, dated 8/30/93, which includes performance statements and radiation figures on their Ura-Rad seals which have been in service for over 10 years. See sub-attachment B.2.

2. Site Meeting: A meeting on 12/4/96 at WESF with Lee Janin, Juergen Rasmussen, Charles Li, and Karl Walterskirchen resulted in discussions of the history of the use of the hot cells from the hot start in 1974 until today. See Hot Cell History, Attachment C.

3. Lee Janin: Lee has become my principal contact at WESF. He has requested Larry get us a radiation level survey of the cells soon so we can use them in our calculations. Before we push for this I need input from Charles Li on how useful the data will be in light of the lack of information we have right now on the seal material. 
Lee also mentioned that QC may not accept the Ura-Rad seal material now in storage at Hanford. Evidently HCS is not providing sufficient information on the material as required by the procurement document. Considering the information received about the 7 to 12 month shelf live any delays in storage could severely affect any schedule for installing the seals.

4. Elmer Libke: Elmer Libke is the maintenance manager in charge of the latter window change out. Elmer claims the material used for sealing the cerium glass into its frame, sealing the cerium glass module after assembly into building opening, and sealing the main leaded glass module into the building opening was all the same material. He claims it was Adiprene L-83 manufactured by Penberthy (See cc:Mail, KMW to LFJ, $12 / 11 / 96)$ [the manufacturer is actually Uniroyal, see item 7]. The first cerium windows (B-Cell, 1984) were assembled at WESF using the L-83 seals. The later windows (?, 1985-1986) were provided, or refurbished, by Hot Cell Services (HCS) and shipped to WESF for installation. HCS has no recollection of this or confirmation on the seal material used without digging through their archives. Elmer suggested I call Elizabeth Carter who was very involved with window sealing capabitities and worked with Elmer. She is retired but fiving in town (967-5659).

5. Elizabeth Canter: She was very involved with the window refurbishment. She prepared a very comprehensive report on the work including technical data and procedures. She said it could be found as an SD document under her name and/or under "cerium windows." She said they did E-Cell first (and maybe F-Cell). B- and CCell followed. A-Cell windows were replaced in 1988. They used the G-Cell leaded window as a temporary plug during each of the other window refurbishments since they had to let the leaded windows sit and discharge gradually over a period of time after they were pulled. She didn't remember anything about the seal material. Lee Janin called and said he has obtained a copy of her report from Dewey Robbins. He will drop it off at my office today.

6. Dewey Robbins: Dewey filled me in on some of the sequences of the window change outs and feels quite sure that all the windows, including the cerium plates, were refurbished. His recollection on seal material is that it was red (he still has a sample) and they obtained it directly from the vendor that supplied it to HCS. Lee Janin brought me the Elizabeth Carter report ("WESF E-Cell Cerium Coverglass Changeout," SD-WM-ER-013, 11/19/84) which does contain much good information on the cell windows. This report states that the seal material used for the cerium windows was Adiprene L-83 manufactured by Uniroyal. Specification sheets were also included. Copies of this were given to Charles Li for use in his calculations.

7. Charles Li (Radiation Calculations): Charles Li, having received and reviewed all the above mentioned data, met with Chuck Zook and Kart Walterskirchen to discuss what calculation could be performed that could provide the desired surface level radiation criteria required by our scope of work. F-Cell, with the three cesium capsules stored inside and a determinable duration of storage, is the only cell that can be effectively modeled. Nothing can be calculated for the other cells until a radiological survey is performed on all the celis or some estimated dose levels are provided us. Charles will look at the expected life of the cerium window seal in F-Cell based on the estimated location of the capsules in the cell as observed through the window. He will list whatever assumptions he must make to arrive at an estimated remaining life of the $F$ Cell cerium window seal. 


\section{APPENDIX D}

\section{Hot Cells History}




\section{APPENDIX D}

\section{WESF HOT CELL HISTORY}

The following is an approximate history of the WESF hot cells compiled from the various interviews and documents obtained during data collection:

1974: Hot startup occurs for all cells.

A-Cell: Used for removal of radioactive solid waste drums via overhead crane in the canyon. The A-Cell hood was designed for a clean packaging of the solid waste into drums. Difficulties occurred which contaminated A-Cell and altered the waste collection and drum removal process.

B-Cell: Strontium-90 - step 1 processes: chemical treatment, precipitation, filtering, drying and furnace firing.

C-Cell: Strontium 90 - step 2 processes: crushing, tamped, helium purge and cap welding.

D-Cell: Cesium-137, step 1 processes: chem treatment and cesium chloride conversion.

E-Cell: Cesium-137, step 2 processes: Evaporate/melt, melt/cast, helium purge and cap weld.

F-Cell: Decon all capsules, various mechanical and wash down processes used.

G-Cell: Clean area used for capsule welding, weld testing, weighing, cask loading/unioading and entry and exit into service gallery air lock. Also contains a capsule transfer chute into pool area.

1974-1978: About 30\% of the total amount of capsules were processed. The encapsulation processes, when operating, normally ran 24 hours per day five days per week. However, various problems and process modification caused a fair amount of down time during this period.

B and C-Cells: There were process upsets that caused considerable amount of radioactive material spreading throughout these cells. The crushing and tamping process allowed strontium laden dust to cover much of the cell. Water wash was not viable. Brush and dust pan pickup of the waste and placing it in waste canisters via manipulators was the primary cleanup method for strontium.

D-Cell: Eventually the inner cap welding process for both cesium and strontium capsules was located in D-Cell. D-Cell and E-Cell therefore received both cesium and strontium contamination. The stainless steel floor sheathing in Cell-E and possibly D-Cell received multiple penetrations from heavy items being dropped. Washdowns resulted in highly radioactive contaminated wastewater migrating under the floor and into the back wall causing a hazardous condition for possible deterioration of the concrete and reinforcement steel as well as an exposure hazard 
in the service gallery. The affected floor and wall areas in the service gallery are shielded by lead bricks stacked along the wail.

E-Cell: The cesium melter in E-Cell had occasional upsets (burps) that splattered hot ( $700 \mathrm{deg} \mathrm{C}+/$ ) molten cesium-chloride over the cell ceiling, walis, windows and floor. Washing down was a viable cleanup method, however, due to the limited visibility and access to all the corners of the room it is not certain that complete cleanup was accomplished.

1978-1984: Production efficiency improved to produce the remaining $70 \%$ of the capsules. Approximately 1,275 strontium capsules and 600 cesium capsules were produced. The cesium processing was stopped in 1983 and the strontium process in 1984.

1984-1988: It appears that almost all of the windows of the WESF hot cells underwent replacement of the cerium plate glass windows (hot side shield) and refurbishment of the leaded glass windows during this period. D-Cell and $\mathrm{E}$-Cell windows were overhauled in 1984, B-Cell and C-Cell windows in 1986, F-Cell in 1987 and A-Cell and G-Cell completed in 1988.

1988-1996: There was little radiological activity in the A through E-Cells during this period. Some NCAW testing occurred in D-Cell in 1990. However, the estimated radiation exposure to the cell window was considered to be negligible.

All of the cesium and strontium capsules that were in commercial use and recalled were returned to WESF and stored in the pool. The capsules were brought into G-Cell, inspected and returned to the pool. There were four strontium capsules and approximately 786 cesium capsules returned through G-Cell. A very rough unpacking and inspection time of three hours per capsule is estimated for exposure inside G-Cell. Most of the capsules were at or near the radiation levels when they were returned.

Three of the returned cesium capsules were classified as possibly damaged and unsuitable for storage in the pool. They were moved into F-Cell where they remain in storage. Plans for their disposition have not been determined. It is estimated that their radiation level is close to the original 47,000 curies/capsule value.

There are two pipe-type waste containers stored in D-Cell of reasonably high radiation level. No radiation levels have been measured on these containers. However, it is assumed the dose rated from these will not exceed the estimated $3,500 \mathrm{R} / \mathrm{hr}$ dose rate level provided as criteria.

A considerable amount of debris remains in A-Cell and B-Cell. The other cells have lesser amounts of contaminated waste and most of the abandoned process equipment. WESF is scheduled to remove all, or as much as feasible, of the solid waste by the end of FY 97 . 


\section{APPENDIX E}

\section{Seal Material Specifications}




\section{HOT CELL SERVICES}

corporation

22626 85th Place South - Kent, WA 98031-2469 • (206) 854-4945 FAX (206) 854-4947

E-mail: hotcell 1 interserv.com

-

Home Page: http://www.hotcell.com

February 28, 1997

HCSC-12383-CK

Mr. Kar Walterskirchen

Flour Daniel Northwest

PO Box 1050

MSIN: G3-17

Richland WA 99352-1050

Ref: Condition of WESF Hot Cell shielding windows

Dear Mr. Walterskirchen :

This letter is a follow-up to my telephone conversation with you earlier this week.

Mr. Larry Nunn at WESF was kind enough to show me through the facility and allow me to examine the shieiding windows.

We examined all nine of the shielding windows. The following observations were noted.

(1) C - Cell window has a severe oil leak on the window chamber at the hot side. Oil level in the window is about one third full.

(2) Four of the other windows chambers are not totally filled, which may be an indication of a small oil leakage at the hot side of the windows.

(3) The seal and compression gaskets installed on the window chamber units both hot and cold side are all 1/8" thick koroseal, which are rated at $1 \times 10^{8}$ rads. This particular gasket material when heavily irradiated becomes hard and brittle, then cracks allowing the oil to leak from the window. The severity of the crack governs the oil volume lost.

(4) No oil leaks were found on the operation sides of the windows.

(5) The oil level in the oil expansion tanks were either down or empty, and the neoprene bellows above were deteriorated and deflated.

(6) F - Cell window looked reasonably clear, but had hints that the shielding glass may be starting to brown. This is the cell where three defective cesium capsules are stored.

(7) A red colored gasket is installed on the barrier shield frames. This was observed through the shielding windows. This conforms with information obtained that Adiprene L-83 material was used as the barrier seal gasket material. 
Hot Cell Services tested this material in the early $80^{\text {"s }}$ before it selected URA-RAD as the more suitable seal material for the hot cell windows. Although Adiprene L-83 is now rated at $1 \times 10^{9}$ rads, we found it lacking in certain performance characteristics, hence the decision to use URA-RAD.

In view of the above referenced findings, and the proposed plan to place the hot cells in a "laid up" configuration, I recommend that you refurbish three radiation shielding windows each year until all nine shielding windows in the facility are refurbished. I would start with "C" Cell window, then " $F$ " Cell window, and continue with the windows which are already low on oil. The purpose is to restore the clarity of the viewing glass, and eliminate oil leakage. Additionally, I would replace the nitrogen purge system above the windows, eliminating the requirement for a bellows, and connect the oil expansion systems to the building nitrogen supply. This will put the windows in an almost maintenance free situation.

I would also recommend performing a UV light treatment on the hot side of " $F$ " Cell window to remove any browning that may have occurred to the lead glass. This will also reduce the potential for dielectric discharge when the window is extracted.

I would leave the barrier shields in place undisturbed, and plan for their replacement when the cells are eventually reactivated. This recommendation is made based on the fact that the gaskets need replacement, and the glasses and frames are heavily contaminated. The logical conclussion is to replace them with new units." (It should be noted that the glasses are secured in the frames with a molden metal which expands when cooled, and are very difficult to remove from the frames.)

I hope this information is helpful in your evaluation and final determination on what action should be taken on the shielding windows.

Sincerely,

HOT CELL SERVICES CORPORATION

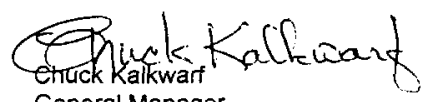

General Manager

Senior Vice President

$\mathrm{CKJjS}$

cc: Mr. Larry Nunn - B \& W Hanford Co. PO Box 1300, MSIN S6-51, Richland WA, 99352-1300 


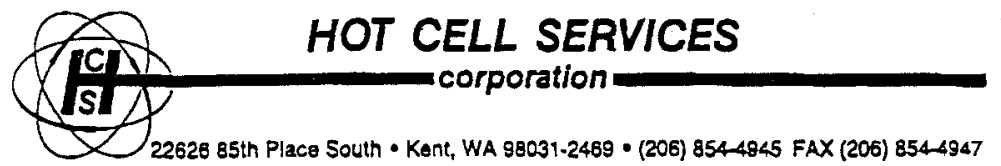

January 15, 1997

HCSC-12230-CK

Mr. Karl Walterskirchen

Flour Danial. Northwest

MSIN: G3-17

Rlehland WA 99352

Ref: Discussion re: seals on WESF Hot Cell shididing windows.

Dear Mr. Walterskirchen :

Thank you for your telephone call this aftemoon regarding the seal gaskets on the WESF Hot Cell shielding windows.

My recollection is that the shielding window gaskets were changed out by Rockwell personnel using an Adaprene L-83 gasket material in about 1985.

Hot Cell Services had conducted numerous lests prior to this time, in the early 1980's, on many different gasket materials in search of a gaskat material that would hold up on a radiation shlelding window for 10 to 15 years. Adaprene $L-83$ was one of the materials our company tested, and rejected for use on shiolding windows and that time.

We eventually developed a material that has a urethane base, excellent resiliency, good properties in oil, high radiation resistance, with only mild degradation to harsh chemicals. We called the material URA-RAD. OUr URA-RAD material has been in use on hot cell shielding windows since that time. It is rated to withstand a total dose of $1 \times 10^{\circ}$ Rads without significant degradation. 
$1 / 15 / 97$

HCSC-12230-CK

Rockwell personnel elected not to use the URA-RAD material on the shieiding windows due to insurficient data at that time.

I hope you find this information helpful.

Sincerely,

HOT CELL SERVICES CORPORATION

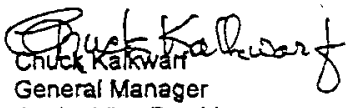

Senior Vica President

CK/s 
CHEMICAL GROUP

Division of UNIROYAL. InC.

World Headquarters

Middlebury, Connecticut 06749
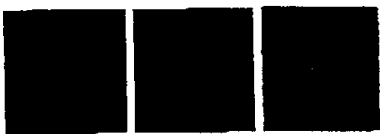
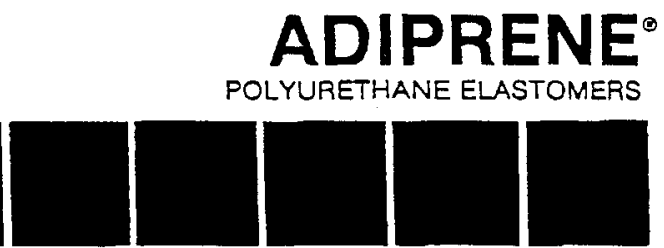

POLYURETHANE ELASTOMERS
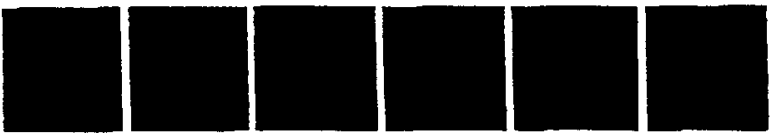

AP-220.L83

\section{ADIPRENE L-83}

\section{A Liquid Urethane Elastomer}

ADIPRENE- L-83 urethane rubber is one of a series of polyether-bssed liquid urethane propolymers which can be cured to a strong. rubbery solid by the reaction of the isocyanate groups with polyamine compounds. When eured with MBCA' urethane curative, ADIPRENE L-83 yield's vulcanizates in the 80-85 duromete: $A$ hardness range. ADIPRENE L-83 can be cast, compression molded, sprayed or spre3d to produce a wide variety of meebanical goods and protecrive and decorative coatings.

ADIPRENE L-83 is a fully saturated polymer having an available isocysnate content of about $3.25 \%$. Although it is a highly viscous fluid to 3 waxy solid at normal storage temperatures, it readily eonverts at $30^{\circ} \mathrm{C}\left[86^{\circ} \mathrm{F}\right.$ ] to a clear liquid baving a Brookfield viscosity of 15 to $30 \mathrm{~Pa} .5$ [15000 to $30000 \mathrm{cP}$ ]. It is relatively easy to process by either batch or machine mixing.

Vuleanizates of ADIPRENE L-83 provide a unique combination of properiesincluding excellent abrasion resistance, resilience, bydrolytic stability and overall mechanieal properties - which make it especially suitable for handling abrasive slumies from mine and mill operations. Vulcanizates of ADIPRENE L- 83 cured with MBCA have been used successfuly in the mining industry to line slurry pumps, agitators, flotation rotors and stators, cyclone separator systems, piping, valves and screens, and in the recreationsl market for roller skate and skatebosid wheels.

Table 1

Typical Properties of ADIPRENE L-83 Prepolymer

(These data are presented to describe the product. and are not intended to serve as specifications.)

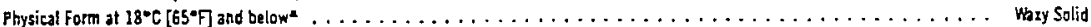

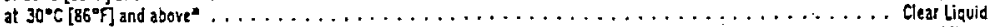

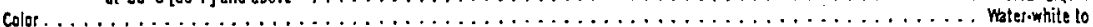

right yellow

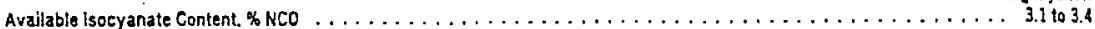

Specilis Gravity

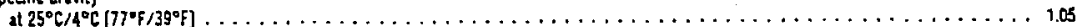

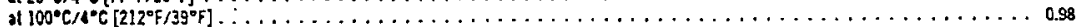

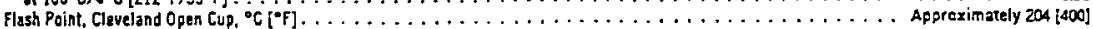

Viscosity, Brookfield. Pa-3 [CP]

(Model LVF, Spindie Ho. 4, 12 rprr)

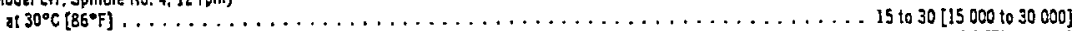

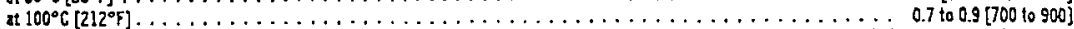

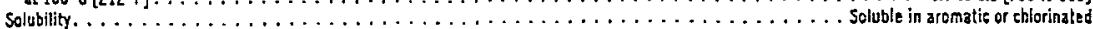
hydrocarbons, ketones and esters

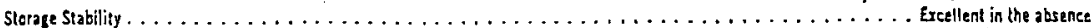
of moisture and heat

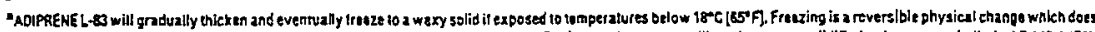
not damage the polymor, but it must be thawed and thoroughiy mixed belart use. For instruetions on handling viscous or solidified polymet. sea bullatin AP-110.1 (AT). "Toxicity and Sale Handthing of ADIPRENE/VIARATHANE"

'MBCA is an abbreviation of 4.4--methylene-bis [2-ehloroaniline].

-Reg. U.S. Pal \& Tm. Off.

Uniroyal Adiprene L-83

Specifications 


\section{Weather Resistance}

Vulesnizates of ADIPRENE L- $\delta 3$ darken and lose streagth if exposed to sunlight. However, compounds may be protected against the effects of weathering with vltraviolet screening materials or combinations of ulUaviolet absorbers and antioxidants. Sereening materials, such as pigments or carbon black, afe effective longer than UV absorbers and are generally preferted UV absorbers afford excellent protection until they are consumed; then the physieal properties of the urethane elastomer ebange at the same tate as in an unprotected compound.

One to three parts of a medium thermal carbon black will provide good sesistance to the effects of weathering without signifcanty altering original properies. A plasticizer such as dioctyl phthalate may be used as a carrier for the carbon black and aids in dispersing it in the polymer.

\section{Orygen and Ozone Resistance}

Compounds of ADIPRENE L-83 are highly resistant to degradarion by oxygen and ozone. The most useful measure of ozone resistance is obtained by testing the vulcanizate in an atmospherc containing 3 ppm ozone. Past experience has shown that materials which resist this eoncentration for several hundred hours are virtually immune to attack by normal atmospheric concentrations of ozone. Higher conceatrations of ozone (c.s., $100 \mathrm{ppm}$ ) are sometimes used for screening of exceptionally ozone-resistant materials. Table VII sbows the resistance of ADIPRENE L-83 formulated per Tsble II to ozone attacis at both $3 \mathrm{ppm}$ and $100 \mathrm{ppm}$ ozone, under static strain conditions.

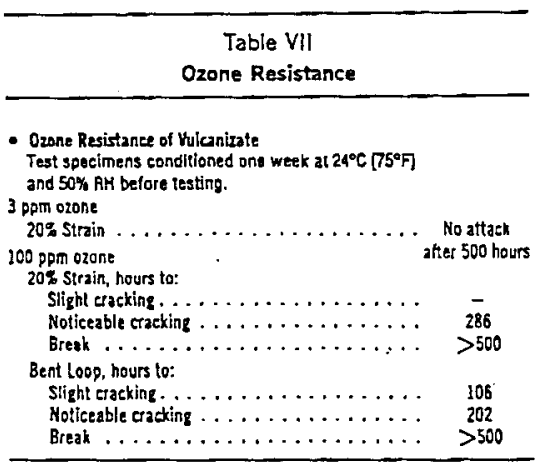

\section{Oil, Solvent and Chemlcal Resistance}

The MBCA vulcanizate of ADIPRENE L-83 formujated per Table II has excellent oil and solvent resistance and is particularly suited for service in non-aromatic lubricating oils and attomotive fuels. Aromatie solvents and polar solvents cause moderate to severe swelling.

Volume changes of vulcanizates of ADIPRENE L-83 after immersion in some oils and solvents are shown in Table VIIl. These dacz should be used as a guide only. Parts should be tested under aetual or closely-simulated service conditions to ensure satisfactory performance.

Table Vill

Oil and Solvent Resistance

Test specimens conditioned one wee $k$ at $24^{\circ} \mathrm{C}\left[15^{\circ} \mathrm{F}\right]$

and $508 \mathrm{RH}$ belore testing.

- Volume Change, 5

After one week at $50^{\circ} \mathrm{C}\left[122^{\circ} \mathrm{F}\right]$ in:

ASTM Oil Na.1................. +2

ASTM Oil Ho. 3. . . . . . . . . . . . . . . . + +19

ASTM Reference fuel A . . . . . . . . . . . . +

ASTM Reference Fuel B . . . . . . . . . . . . +47

Denatured alcohol, 2B............... . . $\ldots 1$

Oloctyl phthalate $\ldots \ldots \ldots \ldots \ldots \ldots \ldots \ldots \ldots \ldots \ldots+32$

Elhylene glysol. .................

Methyl ethyl ketone $\ldots \ldots \ldots \ldots \ldots \ldots \ldots \ldots \ldots \ldots+112$

Patchloroethylent . . . . . . . . . . . . . +85

After one week at $30^{\circ} \mathrm{C}[15 \mathrm{~B}-\mathrm{F}] \mathrm{in:}$

ASTM 0il No. $1 \ldots \ldots \ldots \ldots \ldots \ldots \ldots \ldots \ldots \ldots$ ASTH Oil Ko. 3. . . . . . . . . . . . . . . . . . +22

CELLOSOLVE Acetate ................ .

Dictyl Phthalate ................. $4+42$

Ethylene elycol $\ldots \ldots \ldots \ldots \ldots \ldots \ldots \ldots \ldots \ldots \ldots \ldots \ldots+8$

Kerosene ....................

Tolvene ...................... . . .

\section{Fungus Resistance}

ADIPRENE I rubbers cured with MBCA are inherently resistant to fungus attack. Samples of ADIPRENE L.100 buried for 10 years in moist inoculated soil showed no evidence of atrack (after being rinsed), and vulcanizate properties were unchanged." Vuleanizstes of ADIPRENE L-83 would be expeeted to perform similarly. By conirast, polyester-based urethanes were severely attacked in less than six montbs. Some compounding ingredients (such as plasticizers) are nutrients for fungus growth and should not be used in applications where fungus growh might oceur.

'See bulletin AP-220.L100. "ADIPXENE L.100, A Liquid Utethane Elosiomer." 
Table IX

Oil, Chemical and Solvent Resistance of ADIPRENE

The following tabulacion has been prepared as a guide to the fluid resistance of properly compounded produets made from ADIPRENE. The table should be used as a guide only. Other requirements neeessary for satisfactory performance must also be caken into consideration.

The best.way to determine whether or not the prod. uet will be entifely satisfactory for a given applieation is to test it in actual service. If this is impractical, then tests should be devised which simulate actual service conditions as closely as possible.

Unless otherwise noled, all ratings are at room tem. perature and the concentrations of all aqueous solutions may be considered saturalad The parenthetical temperatures listed are those that were octually used in tests or service applications, but do not necesserily represent temperarure limits.

The $A, B$ and $C$ ratings are based upon data from laboratery tests and records of actual service performance. In some instances, where specific information is not available, $I$ and $X$ ratings are indicated. These are eduealed guesses based upon experience, analogy and a familiarity with the chemistry involved. T mears, "test before usisg but most likely to be satisfactory." $\mathrm{X}$ means, "mos: likely to be unsatisfactory."

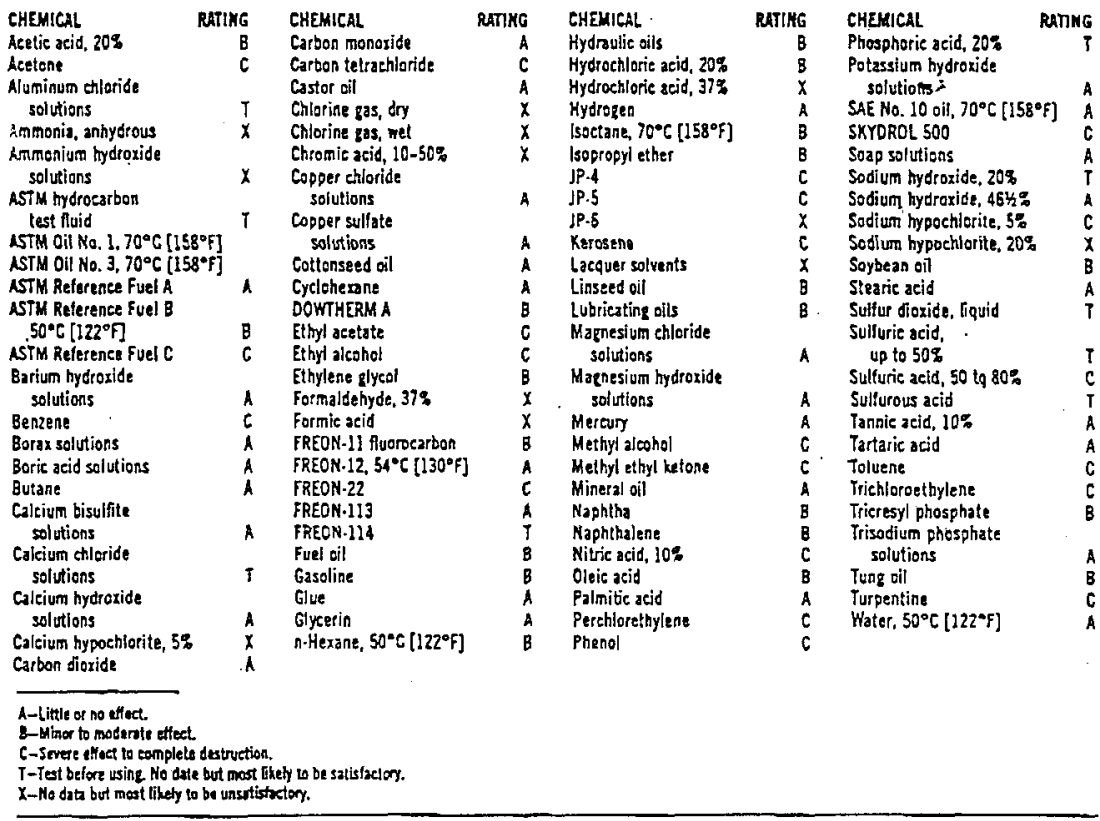




\section{SPECIAL PROPERTIES FOR SPECIFIC APPLICATIONS}

\section{Electrical Properties}

ADIPRENE L-83 riay be used in potting and encapsulation applications. Vulcanizates are serviceable at frequeneies up to 100 kilohertz. Eleerrical properties of a vulcanizate of ADIPRENE L-83 eured with MBCA per Table II, measured at different frequeneies, are showa in Table X.

\section{Table $X$}

\section{Electrical Properties}

Test specimens conditioned one week at $24^{\circ} \mathrm{C}\left[75^{\circ} \mathrm{F}\right]$

and $50 \%$ gi before testing.

- Electrical Properties

Dieloctric Strength, MV/m [rolts/mil] . . . . . 23.2 [590]

DC Volume Resistivity, $\Omega \cdot m[0 h m-6 m] \ldots \ldots 1.5 \times 10^{12}\left[1.5 \times 10^{12}\right]$

$0.1 \mathrm{kHz} 100 \mathrm{kHz}$

Power Factor. . . . . . . . . . . $2.6 \quad 4.8$

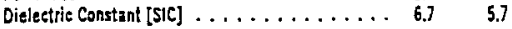

\section{Flammability of Vuleanizates}

Flammability characteristics of ADIPRENE urethane rubber can be changed by addition of some commer. cia! compounds as shown in Tables XXIII and XXIV of bulletin AP.220.LIOO, "ADIPRENE L.100."

\section{Radiation Resistance}

ADTPRENE offered the greatest resistance to the damaging effects of gamma ray radiation of all of the many clastomers and plastics tested by an independent investigator. ${ }^{8}$ Its products appear capable of giving satisfactory service even when exposed to the relatively large gamma ray exposure of $258 \mathrm{kC} / \mathrm{kg}$ ( $1 \times 10^{9}$ roentgens). Vulcanizates of ADIPRENE are more resistant than are vilcanizates of other elastomers to stress cracking, and recain a great amount of their original flexibility and physical toughness while exposed to gamm a radiation.

\section{Outgassing ar}

Products made from ADIPRENE are very stable under high vacuum conditions. They exhibit extremely low weight loss in standard outgassing tests. This property. combined with excellent low temperature performance, suggests applientions in the aerospace feld.

Rober Harington. Hanford Laborstories Operation General Electric Co.

\section{PROCESSING}

At prosessing temperatures (i.e., 70 to $100^{\circ} \mathrm{C}$ [158 to $212 \% \mathrm{~F}$, the low viscosity and reactivity of ADIPRENE L.83 urethane rubber make it relatively easy to process, either by batch or machine mixing. These characteristics also permit produces to be formed from ADIPRENE L-83 by any of a variety of methods which include casting, spraying, and spread coating, It is even possible to make such uniq̨ue items as conveyor belts by these special processing techniques.

\section{POLYMER VISCOSITY}

The viscosity of ADIPRENE L-83 polymer is is 1030 $\mathrm{Pa}$.5 [15000 to $30000 \mathrm{cP}$ ] at $30^{\circ} \mathrm{C}\left[86^{\circ} \mathrm{F}\right.$ ]. Viscosity decreases rapidly with increasing temperature up to about $70^{\circ} \mathrm{C}\left[158^{\circ} \mathrm{F}\right]$ and is relatively constant at temperatures above $100^{\circ} \mathrm{C}\left[212^{\circ} \mathrm{F}\right]$. The relationship beiween viscosity and temperature for ADIPRENE L-83 polymer is shown in Figure 8.

ADIPRENE L. 83 is a waxy solid at normal ambient temperatures. Before using the polymer, heat the drum to about $50^{\circ} \mathrm{C}\left[122^{\circ} \mathrm{F}\right]$ and thoroughly mix the contents by rolling as described in bulletin AP-110.1, - "Toxicity and Safe Handling of ADtPRENE."

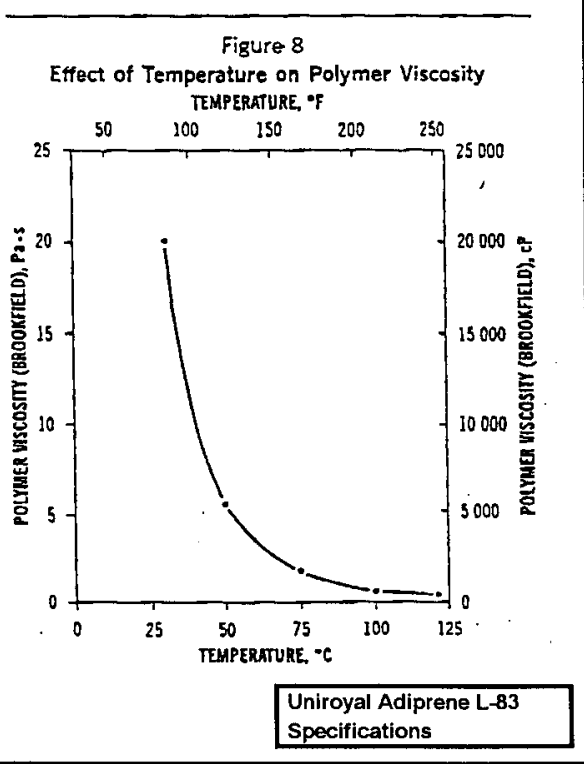




\section{CAST SHEET, POLYURETHATNE, POLYETHER}

\section{SCOPE}

This specification establishes the purchase requirements for a cast polyurethane sheet used to fabricate Radiation Resistant Viewing Window Gaskets.

\section{APPLICABLE DOCUMENTS}

This section in not applicable to this specification.

\section{REQUIREMENTS}

\subsection{Description}

\subsection{Item Definition}

The gasket material shall be a one piece sheet of cast polyurethane, with a nuclear radiation tolerance of $1 \times 10^{8} \mathrm{R}$ total dose and a Shore A hardness of 82 . The polyurethane is produced by reacting a polyether based polyurethane prepolymer such as Vibrathane 602 or Adiprene L-83 with $4,4^{\prime}$-methylene-bis-(2chloroaniline) (generaliy referred to as MOCA or MBCA) in the stoichiometric proportions recommended by the material. supplier.

\subsection{Characteristics}

The dimensions shall be .23 to $.27^{\prime \prime}$ thick $(+/-.04)$ by $45^{\prime \prime}$ by 122 $1 / 2^{\prime \prime}\left(+/-1 / 4^{\prime \prime}\right)$. The top and bottom faces shall be parallel with a flatness of 0.01 inch. There shall be no visible evidence of entrained or surface bubbles larger than 0.010 inches in diameter and there shall be no more than 4 bubbles per square inch. The material shall have a Shore $A$ hardness of $82+/-3$ measured at 8 random locations on the sheet.

\section{QUALITY ASSURANCE PROVISIONS}

\subsection{General}

The seller shall provide and inspection reports as evidence that the sheets provided meet the requirements of Section 3 .

\subsection{Responsibility for Inspection}

The seller is responsible for the performance of all inspection requirements specified herein. The seller may use its own facilities or any commercial laboratory acceptable to the Buyer to perform the inspections. The Buyer reserves the right to perform inspections to verify compliance with requirements set forth in the specification where such inspections are deemed necessary to assure supplied materials and services conform to prescribed requirements. 


\subsection{Qualification Provisions}

The seller shall provide written documentation with each shipment demonstrating conformance to the specification as described in Section 4.3.1.

\subsubsection{Quality Conformance Inspection}

\subsubsection{Dimensional Characteristics and Appearance}

The Seller shall provide measurements of the sheets to assure that they meet the dimensional requirements set forth in section 3.3 of this specification. A description of the inspection results as to the appearance of the sheet shall al so be provided which assures that the entrained and surface bubbles meet the specification requirements identified in section 3.3 of this specification.

\subsubsection{Hardness}

Measurements of the hardness of each sheet, showing compliance with section 3.2 of the specification, shall be provided.

\subsubsection{Mixing Ratios}

The seller shall submit the batch numbers of the materials used and past results of radiation testing (typical).

\section{PREPARATION FOR DELIVERY}

The shipping container shall be adequately labeled for destination and any special handling instructions.

The container shall be adequate to protect gasket material from damage due to normal handling conditions.

The gasketing material shall be laid flat with multiple sheets separated from each other by a release liner and shall be restrained to maintain flatness during shipping and storage.

\section{NOTES}

The following equation may be used to calculate the amount of curing agent required for a desired stoichiometric concentration (curing agent mole ratio), given the percent reactive isocyanate (percent $N C O$ ) for the prepolymer.

Equivalent Weight of Prepolymer $=$ Amine Equivalent $=(42)(100) \% \mathrm{NCO}$.

Ant. of Curing Agent = (Wt. prepolymer)/(Eq.Wt. of Prepolymer)X(Eq.WT. of Curing Agent) X(Curing Agent Mole Ratio) 


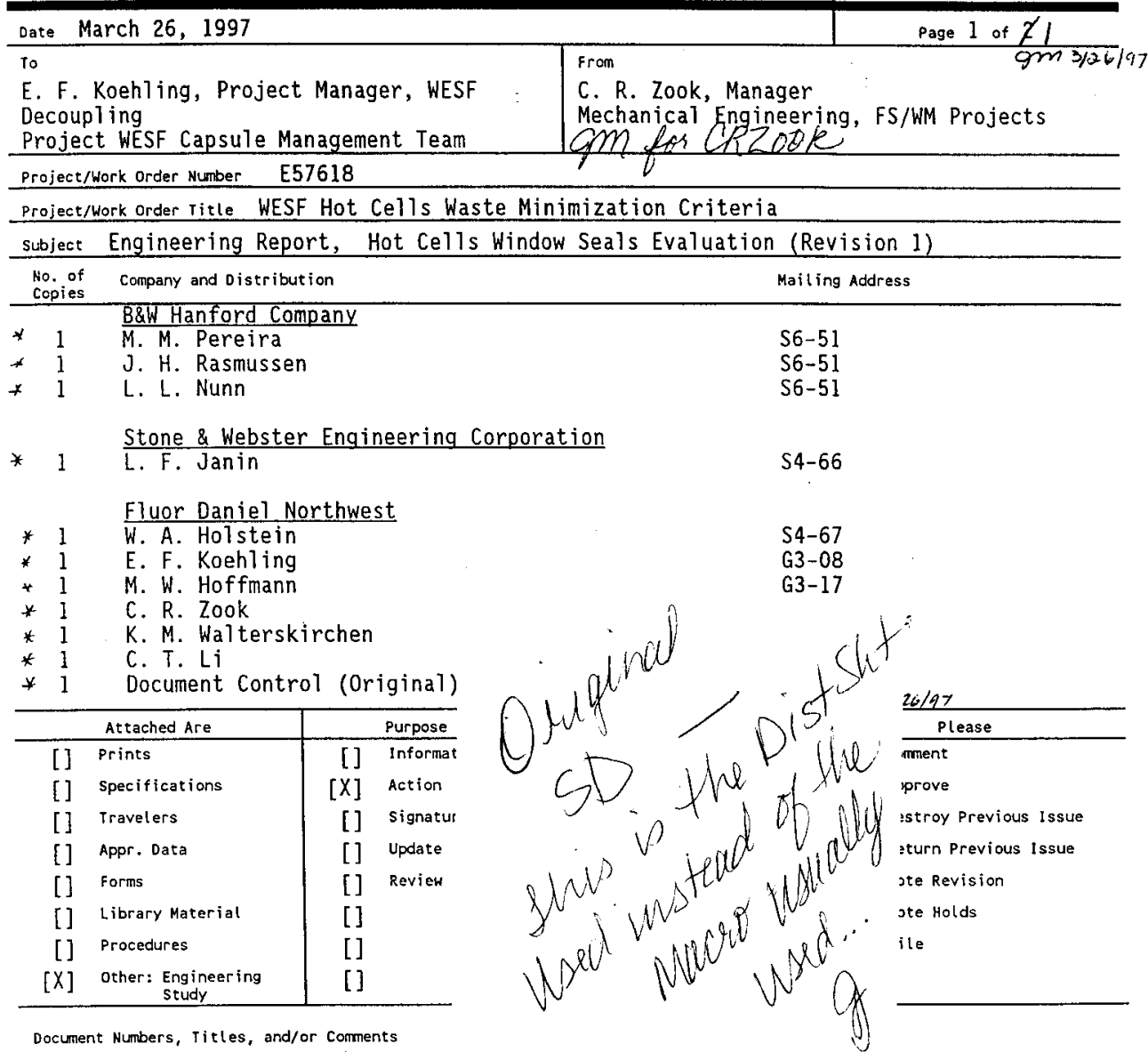

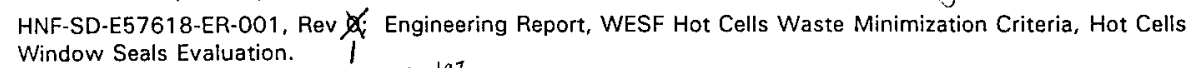
oms/24/a1

This Engineering Study is authorized and provided in accordance with the B\&W Hanford Company Letter of Instructions 2C-96-036-01 (October 22, 1996) and 2C-96--036-02 (December 6, 1996).

This study analyzes the radiation exposure accumulated by the window seals in all of the WESF hot cells. The analysis is based on the history of the hot cell use, including radiation sources, since 1984 . The accumulated radiation doseages of the window seals were calculated. If the hot cells are to be placed in a laid-up configuration, based on this report, actions are recommended to remove existing point sources, replace cerium window seals in F-Cell and refurbish all leaded windows (except for A-Cell). Work should be accomplished as soon ass.possible and at least withing the next three years. 